\title{
杭基礎の非線形地震応答特性とプッシュオー バーアナリシスによる解析法に関する研究
}

\author{
矢部正明 ${ }^{1} \cdot$ 川島一彦 ${ }^{2}$ \\ ${ }^{1}$ 正会員 東京工業大学 博士後期課程 工学部土木工学科（T152-8552 東京都目黒区大岡山2-12-1） \\ 2 フェロー会員 工学博士 東京工業大学教授 工学部土木工学科（广152-8552 東京都目黒区大岡山2-12-1）
}

\begin{abstract}
兵庫県南部地震のように極めて大きな地震動が作用した場合には，橋脚だけでなく基礎構造にも塑性変 形が進展することはやむを得ないと考えられる. 本研究では, 杭基礎で支持された R C 橋脚を有する橋梁 構造物を対象として, 橋脚および杭基礎ともに非線形領域に入る場合に, 橋脚から杭基礎に作用する地震 力特性を明らかにした. そして, 地震時保有水平耐力法に基づく杭基礎の耐震設計を行う際に, フーチン グ底面に作用させる水平力と曲げモーメントの与え方を提案した.
\end{abstract}

Key Words : seismic design, ductility design, pile foundation, push-over analysis

\section{1. まえがき}

平成 7 年の兵庫県南部地震による橋梁の激甚な被害 を経験した後, 平成 8 年の道路橋示方書では, 地震の影 響が大きい全ての構造部材は震度法と同時に地震時保有 水平耐力法により耐震設計されるようになった. これは, 震度法に基づく弾性設計法が長く用いられてきた我国で は画期的な変化と考えられる. 道路橋示方書では, 橋脚 躯体や支承, 基礎を含む橋全体系の耐震設計を地震時保 有水平耐力法で行うと規定されたが, 1980年代以後, 載 荷実験や振動台加震実験も含めていろいろな形で検討が 進められてきた鉄筋コンクリート橋脚系の構造部材に比 較すると, 基礎構造に対する動的耐力や变形性能の評価, さらには地震時保有水平耐力法に基づく基礎構造の耐震 設計法の開発にはまだいろいろな検討課題が残されてい る.

耐震設計の本来のねらいからすれば, 損傷の発見や 復旧の困難な基礎構造には損傷を生じさせず, 塑性変形 は橋脚に生じさせることが好ましいが, 兵庫県南部地震 のように極めて大きな地震動が作用した場合には, 橋脚 だけでなく基礎構造にも塑性変形が進展することはやむ を得ないと考えられる. 橋脚と基礎構造の両者に非線形 化が生じる場合の耐震計算法として, 道路橋示方書では, 橋脚の降伏曲げ耐力に相当する水平力を地震の作用とみ なして基礎構造を耐震設計する方法が示されている ${ }^{1)}$ が, これは静的なつりあいに基づいたものであり, 橋脚一基 礎構造物系の動的応答を見込んだ検討はまだ行われてい
ない.

基礎構造を取り入れて橋脚躯体の弾塑性応答を検討し た研究としては, Ciampoliら ${ }^{3)}{ }^{4)}$, 笹田ら ${ }^{5)}$, 永田 ${ }^{6)}$,

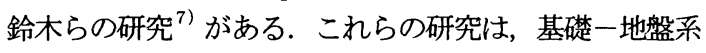
の非線形性をフーチング底面に配置した水平バネと回転 バネによって表現し, 基礎や地盤の剛性や逸散减衰が橋 脚躯体の応答塑性率, 橋脚と基礎の履歷吸収エネルギー に与える影響を検討している. これらの研究では, いず れも橋脚の非線形応答の解明に解析の中心があり, 基礎 構造は簡単なばねによってしかモデル化されていない. このように, 地中部における杭の変形や断面力などを上 部構造系の非線形応答とともに検討した研究はほとんど 行われていない.

以上のような背景のもとに, 本研究では, 杭基礎で支 持された R C 橋脚を有する橋梁構造物を対象として, 橋 脚および杭基礎ともに非線形領域に入る場合に，橋脚か ら杭基礎に作用する地震力特性を明らかにし, 動的応答 を考慮したプッシュオーバーアナリシスに基づく耐震設 計法を提案するものである.

\section{2. 解析対象橋梁と地震時保有水平耐力法による 耐震設計}

\section{（1）解析対象橋}

解析対象橋脚および杭基礎を周辺地盤条件とともに図 -1に示す. これは積層ゴム支承を水平地震力分散支承と 

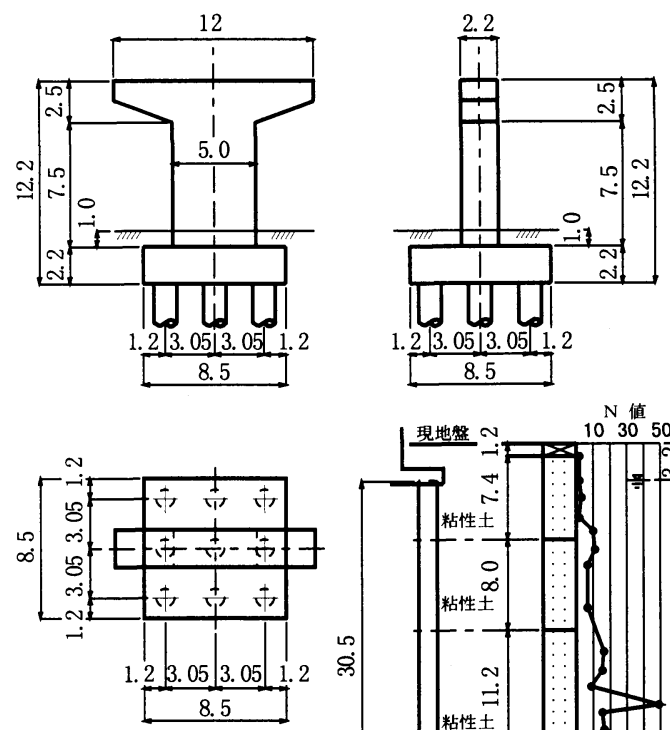

(単位 : m)

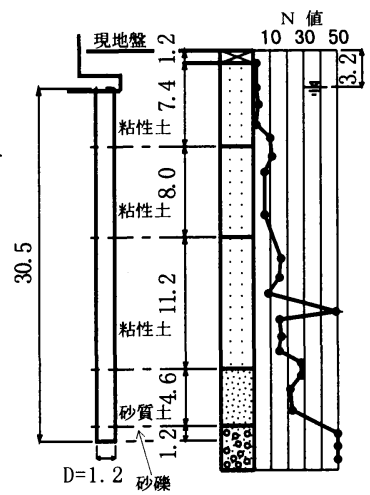

図-1 対象とした橋脚・杭基礎と地盤条件

して用いた 5 径間連続鋼 I げた橋の一部を取り出したも のである. この橋は, 平成 8 年の道路橋示方書に基づい て震度法と地震時保有水平耐力法によって耐震設計され

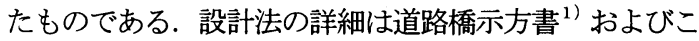
れに関連した図書 ${ }^{2)}$ に示されているが，以下には本解析 に必要な最小限の事項に限って示すこととする.

地表面下 $30 \mathrm{~m}$ にある砂礫層上面を耐震設計上の基盤面 とみなすと, 微小ひずみ時のせん断岡性を用いた表層地 盤の固有周期は1.17秒程度であり, 而震設計上の地盤種 別は而種地盤と判定される. 本研究では, 図-1に示した 橋脚・杭基礎系だけを取り出し, 橋軸方向に地震動が作 用した場合に着目して解析を行う。

\section{（2）橋 脚}

図-2は，橋脚断面を示したものである．軸方向鉄筋 として，橋軸方向の各面にD29（SD295）が 2 段でそれ ぞれ78本，橋軸直角方向の各面にD29（SD295）が 1 段 でそれぞれ13本配置されており，軸方向鉄筋比は $1.06 \%$ である. 軸方向鉄筋の段落しはされていない. 帯鉄筋と しては， 1 段めと 2 段めの軸方向鉄筋に沿わせてD16 （SD295）を150mm間隔に配置すると同時に，同径，同 材質の中間帯鉄筋を橋軸直角方向に 1 本, 橋軸方向に 4 本配置している. 帯鉄筋, 中閒帯鉄筋にはともに, 135 度に曲げた $8 d$ ( $d$ は鉄筋径) のフックを設けている. 帯鉄筋の体積比 $\rho_{s}$ は $0.53 \%$ である.

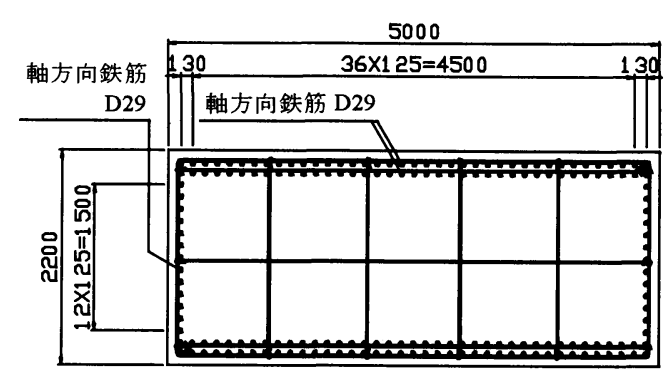

(a ）躯体基部の断面

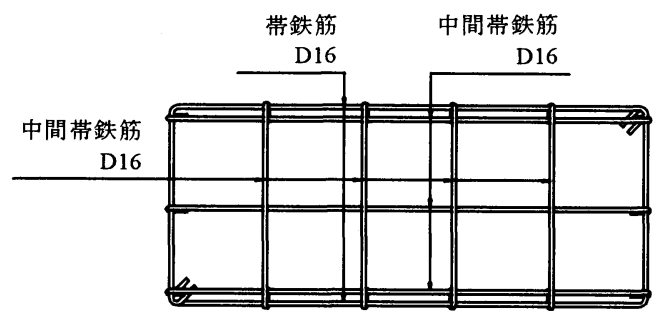

（b）帯鉄筋の配置

図-2 橋脚 躯 体の配 筋 図

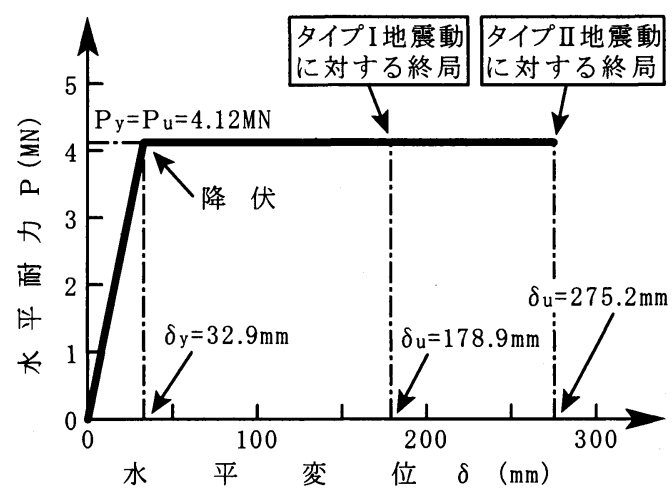

図-3 橋脚の水平力一水平変位関釈

図-3は, 地震時保有水平耐力法に用いる上部構造慣性 力作用位置における水平力と水平変位の関係を示してい る. 図では道路橋示方書に基づいて海洋型大規模地震に 相当するタイプ I 地震動と兵庫県南部地震のような直下 型地震に相当するタイプII 地震動では, 異なる終局変位 が定義されているが，これはコンクリートの終局ひずみ としてタイプ I とタイプII では異なった值が与えられて いるためである.

表-1に示したように, 本橋脚ではせん断耐力 $P_{s}$ が $7.58 \mathrm{MN}$ と終局水平曲け耐力 $P_{u}$ （=地震時保有耐力）の 4.12MNを上回っており,この橋脚は曲げ破壊先行型と 
表-1＼cjkstart鉄筋コンクリート橋脚躯体基部の耐震設計結果

（橋軸方向）

（a ）震度法による耐震設計（設計水平震度 0.3 )

\begin{tabular}{|c|c|cc|}
\hline \multirow{2}{*}{$\begin{array}{c}\text { 応力度 } \\
\text { の照 }\end{array}$} & コンクリートの压縮応力 & 6.2 & $<10.3 \mathrm{MP}_{\mathrm{a}}$ \\
\cline { 2 - 4 } & コンクリートのせん断応力 & 0.29 & $<0.32 \mathrm{MP}_{\mathrm{a}}$ \\
\cline { 2 - 4 } & 鉄矨の引張応力 & 125.3 & $<264.8 \mathrm{MP}_{\mathrm{a}}$ \\
\hline
\end{tabular}

（b）地震時保有水平耐力法による耐震設計

\begin{tabular}{|c|c|c|}
\hline せん断耐力 $\mathrm{P}_{\mathrm{s}}$ & \multicolumn{2}{|c|}{$7.58 \mathrm{MN}$} \\
\hline $\begin{array}{c}\text { 終局水平耐力 } \mathrm{P}_{\mathrm{u}} \\
\text { (地震時保有水平耐力 } \mathrm{P}_{\mathrm{a}} \text { ) }\end{array}$ & \multicolumn{2}{|c|}{$4.12 \mathrm{MN}$} \\
\hline 破壊形態 & \multicolumn{2}{|c|}{ 曲げ破壊先行 } \\
\hline 地震動のタイプ & タイプ $\mathrm{I}$ & タイプ II \\
\hline 設計水平震度 $\mathrm{k}_{\mathrm{h} \mathrm{c}}$ & 1.0 & 1.5 \\
\hline 等価水平震度 $\mathrm{k}_{\mathrm{he}}$ & 0.50 & 0.46 \\
\hline 慣性力 $\mathrm{k}_{\mathrm{h} \mathrm{e} ・ \mathrm{~W}}$ & $3.95 \mathrm{MN}$ & $3.64 \mathrm{MN}$ \\
\hline
\end{tabular}

判定される. 許容塑性率 $\mu_{a}$ は, タイプ I , タイプII 地 震動に対してそれぞれ2.48，5.91と求められ，このため, 次式による等価水平震度 $k_{h e}$ はそれぞれ $0.50,0.46$ とな る.

$$
k_{h e}=\frac{k_{h c}}{\sqrt{2 \mu_{a}-1}}
$$

ここで, $k_{h c}$ は地震時保有水平耐力法に用いる設計水平 震度であり, 本橋ではタイプI , タイプI地震動に対し て，それぞれ1.0，1.5となる．曲げ破壊先行型となる橋 脚の等価重量 $W$ は, 标重量 $W_{U}$ と橋脚躯体の重量 $W_{p}$ か ら式（2）で求められる.

$$
W=W_{U}+0.5 \cdot W_{p}
$$

式 (1) による等価水平震度 $k_{h e}$ と式 (2) による等 価重量 $W$ に相当する慣性力 $k_{h e} W$ が橋脚の地震時保有 水平耐力 $P_{a}$ （=終局水平耐力 $P_{u} ）$ 以下となるように設 計した断面が, 前出の図-2である. なお, 道路橋示方書 によればさらに残留変位の照査が必要であるが，図-2に 示した断面はこれを満足する.

\section{（3）杭基礎}

基礎は径 $1.2 \mathrm{~m}$, 長さ $30.5 \mathrm{~m}$ の現場打ち杭 3 列@ 3 本 $=9$ 本から構成されている. 地震時保有水平耐力法では, 図-4(a)に示すようにフーチング底面位置に，これより上 に存在する構造部分の重量（析の重量 $W_{U}$, 橋脚重量 $W_{p}$, フーチング重量 $W_{F}$ ，土被り重量 $\left.W_{G}\right)$ を初期荷 重として作用させた状態で, 図-4(b)に示すように析, 橋 脚，フーチングの慣性力を作用させる. 図-4(c)に示すよ うにフーチング底面に生じるモーメント $M_{F 0}$ とせん断 力 $F_{F 0}$ を求め, フーチングの並進および回転により上

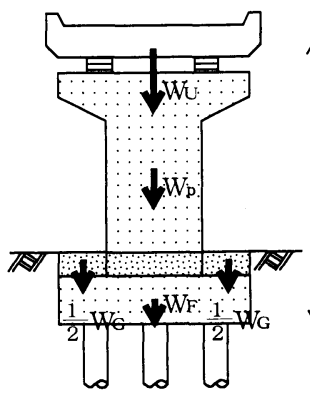

(a) 自重

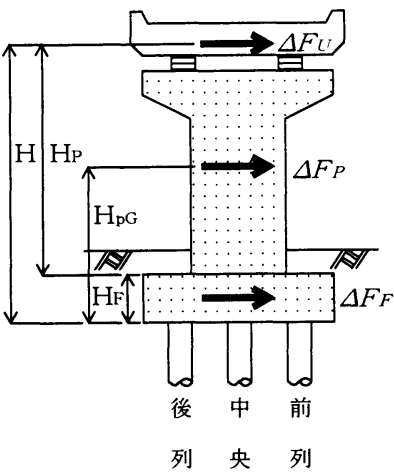

（b）慣 性 力

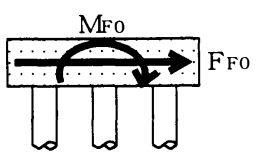

（c）フーチング底面に作用させ る水平力と曲げモーメト

図-4 基礎の水平力一水平変位関係を求めるために作用さ せる自重と慣性力

部構造慣性力作用位置に生じる水平変位 $\delta_{F}$ を求める. 地震時保有水平耐力法により杕および橋脚に作用させる 水平震度を $k_{h c}$, フーチングに作用させる震度を $k_{h G}$ と すると，本橋では，III種地盤のタイプII地震動を考慮す ると, $k_{h c}=1.5, k_{h G}=0.6$ となる. ここでは, この比 率を保持したまま，桁および橋脚，フーチング底面の水 平力を荷重漸増法により与えるものと仮定する．米国等 では，耐震設計一の適用を目的にした非線形系に対する 荷重漸増法をプッシュオーバーアナリシス (Push-over Analysis）と呼んでおり ${ }^{8)}$, 本研究でもこの名称を使う ことにする. 荷重の分割数を $N$ とすると, 桁, 橋脚, フーチングに作用させる増分水平力 $\Delta F_{U}, \Delta F_{p}, \Delta F_{F}$ は，それぞれ以下のように与えられる.

$$
\Delta F_{U}=\frac{k_{h c} \cdot W_{U}}{N} ; \Delta F_{p}=\frac{k_{h c} \cdot W_{p}}{N} ; \Delta F_{F}=\frac{k_{h G} \cdot W_{F}}{N}
$$

この増分水平力によって第 $n$ 回目の載荷によりフーチ ング底面に作用する水平力 $F_{F 0}$ およびモーメント $M_{F 0}$ は以下のように与えられる。

$$
\begin{gathered}
F_{F 0}=\frac{n \cdot k_{h c}}{N}\left(W_{U}+W_{p}+\beta \cdot W_{F}\right) \\
M_{F 0}=\frac{n \cdot k_{h c}}{N}\left(W_{U} \cdot H+W_{p} \cdot H_{p G}+\frac{1}{2} \cdot \beta \cdot W_{F} \cdot H_{F}\right)
\end{gathered}
$$




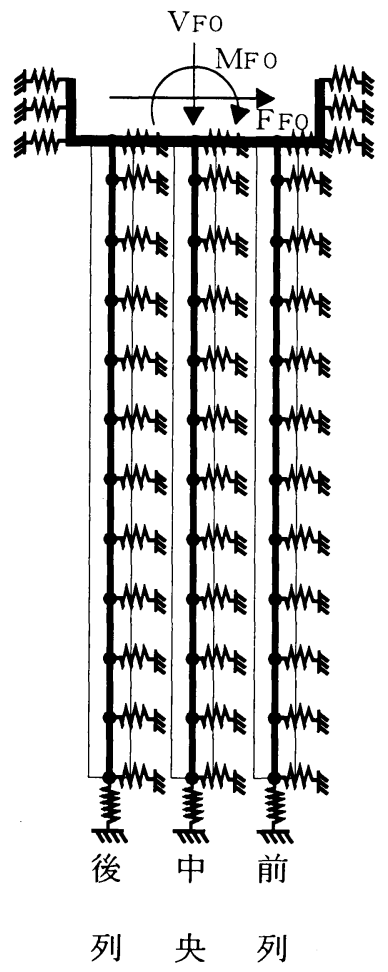

図-5 地震時保有水平耐力法に用いる杭基礎の解析モデル

ここで, $\beta=k_{h G} / k_{h c}, H_{p G}$ はフーチング底面から橋 脚躯体の重心位置までの距離, $H_{F}$ はフーチングの高さ である.なお，式（4）では，杭体の慣性力は考慮され ていない.

杭は図-5に示すように、地盤バネを介して地盤に支 持されているとしてモデル化する．基礎〜地盤間バネは, フーチングとその前面に位置する周辺地盤を結ぶ水平方 向バネ, 杭とその周辺地盤を結ぶ水平方向バネ, 杭先端 と支持地盤を結ぶ鈆直方向バネに分けられる．杭の分割 数は, 杭の配筋や周辺地盤の地層構成に応じて変化する が，杭に生じる曲げモーメントが大きくなる区間や杭の 曲げモーメントが急変する区間では，分割を細かくする 必要がある. 水平力がフーチングに作用した場合に, 圧 縮側となる杭列を前列, 引張側となる杭列を後列, 両者 の中央にある杭列を中央と以下呼ぶことにする.

式（4）の荷重を受けると，杭は前列もしくは後列 から順次降伏していくが, 道路橋示方書では全ての杭列 において杭が降伏する時，もしくは杭先端に作用する軸 力が押込み支持力の上限值に達する時を杭基礎としての 降伏と定義されている. ここで, 杭体の降伏とは, 杭体 の最外縁の軸方向鉄筋が最初に降伏する時（初降伏）を 指している.

図-6は，本解析で対象とする橋脚と杭基礎に対して プッシュオーバーアナリシスを行った結果であり，上部

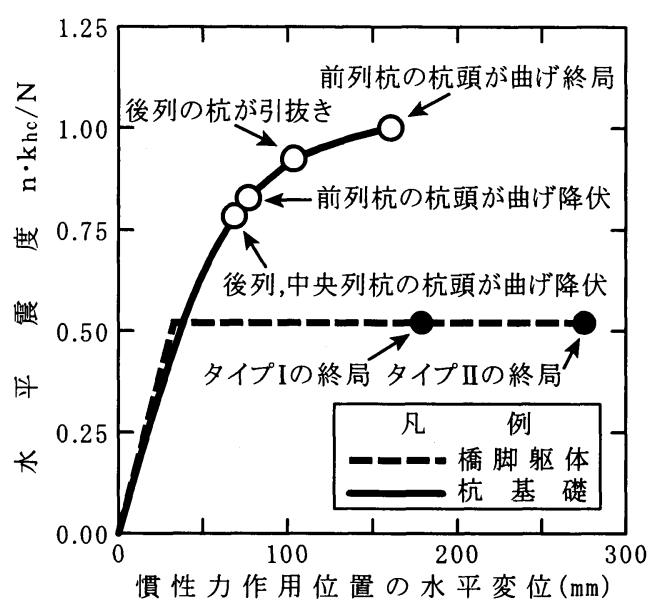

図-6 プッシュオーバーアナリシスから求めた杭基礎 と橋脚の水平震度一水平変位関係

構造慣性力作用位置における水平震度と水平変位の関係 を示している.この基礎では，まず式（4）に示す $n k_{h c} / N=0.78$ で後列の杭が最初に杭頭で降伏し, これ とほぼ同時に中央の杭も杭頭で降伏する.さらに $n k_{h c} / N=0.83$ で前列の杭も杭頭で降伏して, 杭基礎と しての降伏に達する，したがって，道路橋示方書の定義 に従えば, この杭基礎の降伏水平震度は 0.83 と求めら れることになる. これに対して，図-3に示したように， 橋脚の終局耐力 $P_{u}$ は $4.12 M N$ であり，これを式 (2) による等価重量 $W=7.91 M N$ で除すことにより，橋脚の 降伏水平震度 $k_{h p}$ は 0.52 と求められる. この関係も, 図 -6に示している. これより, 基礎の降伏水平震度は橋脚 の降伏水平震度よりも大きく, 道路橋示方書の定義に従 えば, 本基礎は耐震性があると判定されることになる.

\section{3. 解析モデル及び入力地震動}

\section{（1）モデル化の基本方針}

このような桁一橋脚一杭基礎系からなる構造系を解 析するために，これを図一7に示すようにモデル化した. 上部構造の軸方向剛性は橋脚や杭の曲け剛性に比較して 大きいため 1 質点で表すこととし，積層ゴム支承は線形 せん断バネによってモデル化した．橋脚躯体については, 橋脚基部から $1.1 \mathrm{~m}$ 塑性ヒンジ区間は非線形回転バネ で，また，これ以外の区間は線形梁要素でそれぞれモデ ル化した，ただし橋脚躯体のうち，横梁部は剛体とした. さらに, フーチングも剛体とし，橋軸方向の並進と橋軸 直角軸回りの回転を有する 2 自由度系とした．杭は各列 ごとに, 橋軸直角方向に存在する 3 本の杭をまとめ, 各 


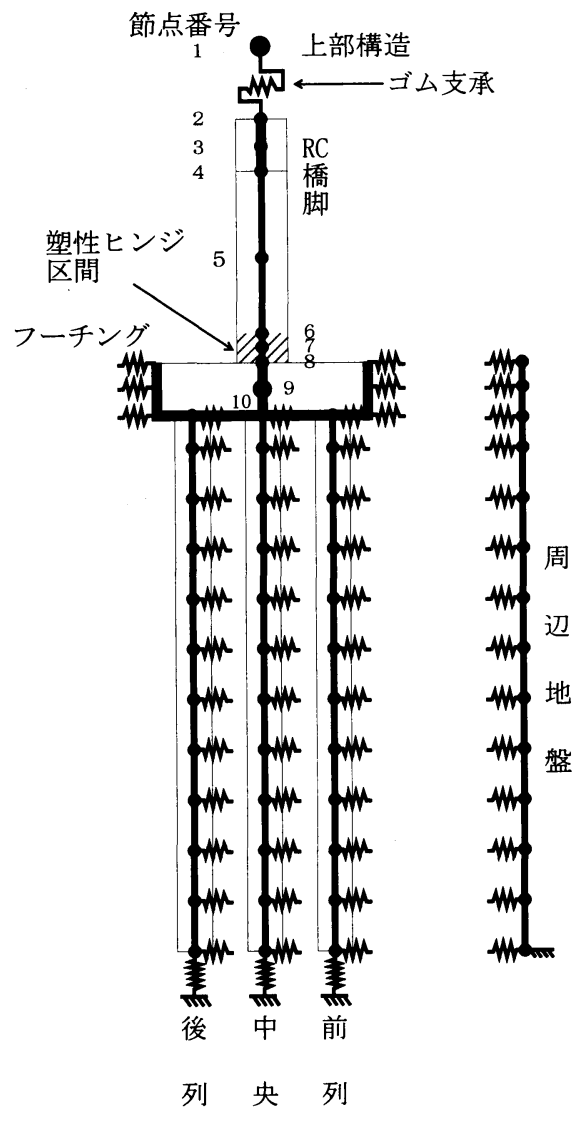

図-7 RC橋脚一杭基礎一周辺地盤系の解析モデル

列の杭の剛性および質量は杭 1 本当たりの值の 3 倍とし た. また, 杭は, 非線形梁要素でモデル化し, 杭の質量 には杭に囲まれた範囲の地盤の質量を付加質量として見 込んだ.

基礎と地盤間には鉛直方向のせん断力は作用しない と仮定し, 杭周面の摩擦と杭先端地盤の影響は, 既往の 鉛直載荷試験結果に基づいて杭の軸方向剛性を補正する 形で考慮した ${ }^{1)}$

地盤は，基礎の影響を受けない自然地盤として 1 次 元非線形せん断バネモデルによって表した．3列の杭と 地般間の水平方向の拘束は後述するように非線形せん断 型バネによって表した.

\section{（2）橋脚及び杭のモデル化}

橋脚の塑性ヒンジ区間は，図-8に示すようにひびわれ 点を無視した剛性低下型のTakedaモデルで表した ${ }^{9)}$ 。こ こで，ひびわれ点を無視することにしたのは，地震動が 作用し始めていったんクラックが生じた後には主要動の

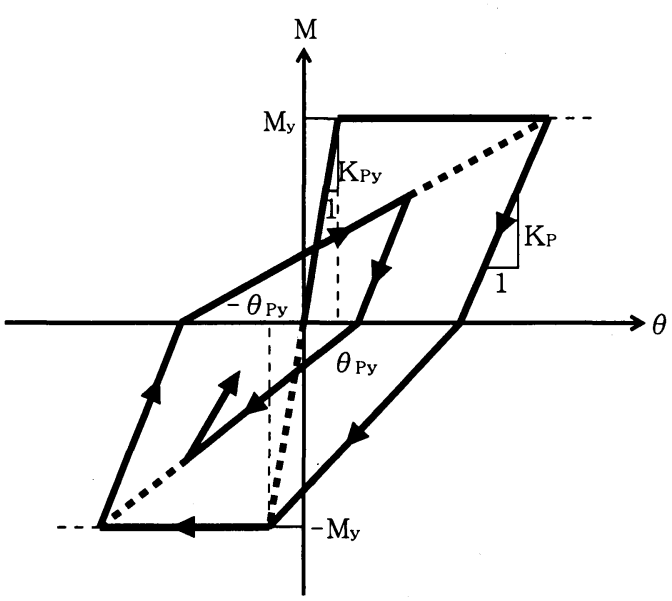

図-8 橋脚の塑性ヒンジ区間における曲げモーメントと 回転角の復元力特性

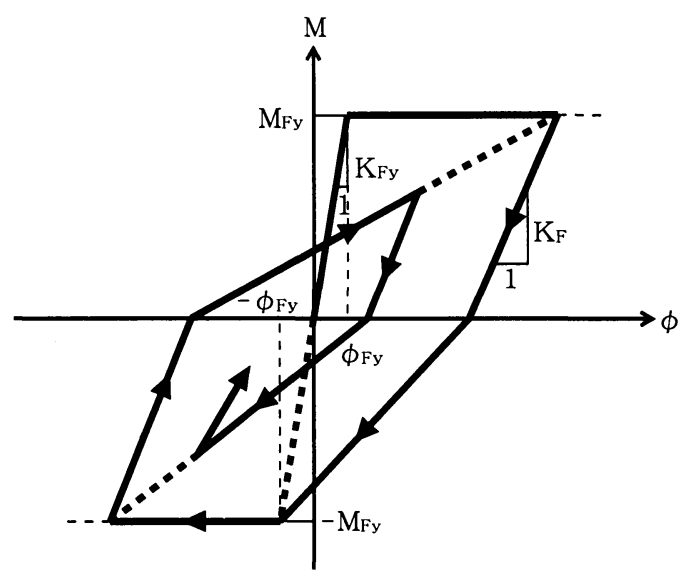

図-9＼cjkstart杭の曲げモーメントと曲率の復元力特性

応答は, クラックが入った後の剛性に支配されると考え たためである. 降伏回転角 $\theta_{p y}$ および除荷剛性 $K_{p}$ は次 式により与えた.

$$
\begin{aligned}
\theta_{p y} & =\frac{\delta_{y}}{H_{p}-L_{p} / 2} \\
K_{p} & =\frac{M_{y}}{\theta_{p y}} \cdot\left|\frac{\theta_{p}}{\theta_{p y}}\right|^{-\alpha}
\end{aligned}
$$

ここで,

$$
M_{y}=P_{y} \cdot\left(H_{p}-L_{p} / 2\right)
$$

ここで, $\delta_{y}$ : 橋脚の上部構造慣性力作用位置の降伏水 平変位, $H_{p}$ : 橋脚基部から上部構造慣性力作用位置ま での高さ, $L_{p}$ : 塑性ヒンジ長, $\theta_{p}$ : 橋脚基部の塑性ヒ ンジに生じる塑性回転角， $\alpha$ : 除荷剛性の低下度を表す 係数, $P_{y}$ : 橋脚の上部構造慣性力作用位置の降伏水平 


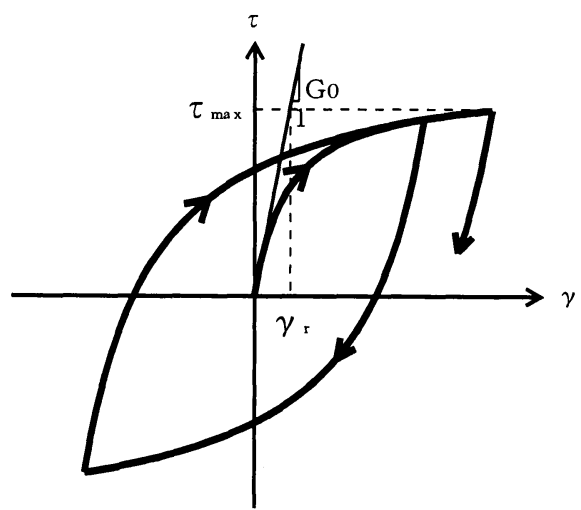

図-10 地盤の復元力特性

耐力である. 除荷剛性の低下度を表す係数 $\alpha$ は, 載荷実 験結果に基づき，以下の解析では $\alpha=0.5$ とした.

場所打ち杭の耐力や変形特性に関する研究は少ないが, $\mathrm{RC}$ 橋脚と同様な特性を示寸と考えられることから，こ こでは図-9に示すように橋脚と同様にひびわれ点を無視 した剛性低下型のTakedaモデルによって表わすこととし た. ここで, 杭の降伏曲げモーメント $M_{F y}$, 降伏曲率 $\phi_{F y}$ は次式によって求めた.

$$
M_{F y}=M_{F u} ; \phi_{F y}=\phi_{F y 0} \times \frac{M_{F u}}{M_{F y 0}}
$$

ここで, $M_{F u}$ は杭の終局曲げモーメント， $M_{F y 0}$ は杭 の初降伏曲げモーメント， $\phi_{F y 0}$ は初降伏時の曲率であ る. また, 杭の除荷剛性 $K_{F}$ は, 次式のように与えた.

$$
K_{F}=\frac{M_{F y}}{\phi_{F y}} \cdot\left|\frac{\phi}{\phi_{F y}}\right|^{-\alpha}
$$

ここでは， $\alpha$ は橋脚と同様に 0.5 とした.

地震時には, フーチングの回転運動により前列と後列 の杭に作用する軸力は時間的に変化するため, 杭体の曲 げモーメントー曲率関係も変化する．しかし，ここでは 解析を簡単にするために, フーチング底面より上に存在 する全死荷重に相当する鉛直力を均等に杭が分担すると した場合の軸力が作用するとして杭体の曲げモーメント 一曲率関係を求めることとした。

\section{（3）地盤のモデル化}

周辺地盤の応答は 1 次元せん断振動モデルによって計 算することとし, 復元力は, 図-10に示すHardin-

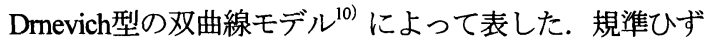
み $\gamma_{r}$ は, 豊浦標準砂および沖積粘性土に対するせん断 剛性一せん断ひずみの実験値 ${ }^{11)}$ ，12) を参考に, 粘性土で は0.6〜2.0\%，砂質土では0.4\%とした.

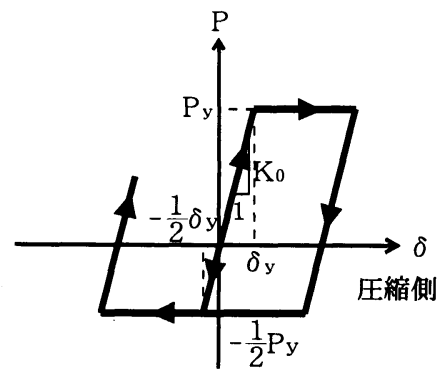

(a) 前列の杭

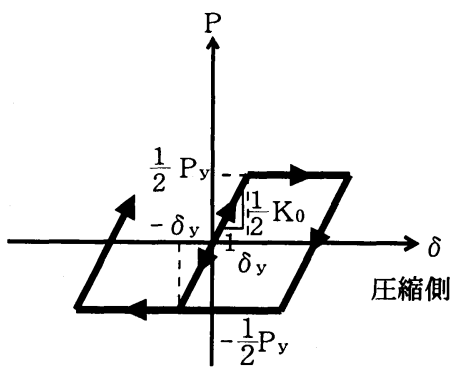

(b) 中央列の杭

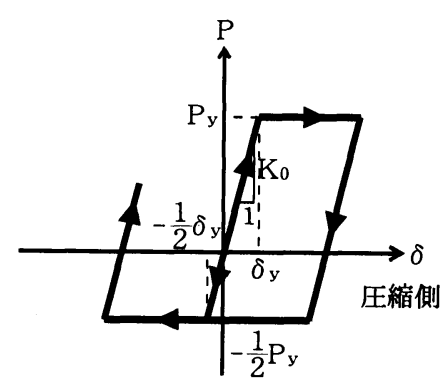

(c) 後列の杭

図-11 基礎〜地盤間を結ぶ水平方向バネの復元力特性

\section{（4）杭〜地盤間バネのモデル化}

杭基礎は，バネを介して 1 次元地盤モデルに支持され ているとモデル化している. このようなモデル化では, 基礎〜地盤間の動的相互作用を正確に表すことはできな いが，基礎が大規模でない場合には，図一7のようなモデ ルでも実用的な精度で解を得ることができる．この理由 は，基礎～地盤間の相互作用バネの振動数依存性は，高 振動数域て顕著となるのに対して，杭基礎の地震応答を 支配するのは低振動数域の振動モードであり, 周辺地盤 が大きな非線形性を示すような場合は，この傾向がより 顕著となるためである.

杭と地盤を結ぶバネの極限支持力 $P_{y}$ は, 次式で与え られている1) 


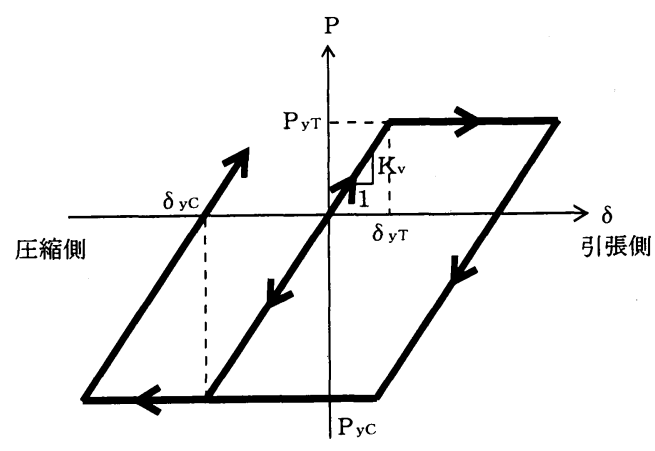

図-12 杭先端〜地盤間を結ぶ鉛直方向バネの復元力特性

$$
P_{y}=\eta_{p} \cdot \alpha_{p} \cdot P_{u}
$$

ここで， $\eta_{p}$ は群杭効果を考慮した極限支持力の補正係 数, $\alpha_{p}$ は単杭における極限支持力の補正係数, $P_{u}$ は受 働土圧強度であり， $\eta_{p} \cdot \alpha_{p}=1.5$ (粘性土地盤の場合）， 2.54 (砂質土地盤の場合) である.

地盤バネの剛性（バイリニアモデルの初期剛性） $K_{0}$ は, 杭位置によらず次式で与えられている ${ }^{1)}$.

$$
K_{0}=\eta_{k} \cdot \alpha_{k} \cdot D \cdot \Delta \ell \cdot k_{h}
$$

ここで， $\eta_{k}$ は群杭効果を考慮した地盤反力係数の補正 係数, $\alpha_{k}$ は単杭における地盤反力係数の補正係数, $D$ は杭径， $\Delta \ell$ は地盤バネの間隔， $k_{h}$ は地盤反力倸数であ る. ここでは, 道路橋示方書に基づいて, $\eta_{k}$ は2/3とす $ろ^{1)}$. 動的解析では, 式（11）により地盤反力係数 $k_{h}$ から，地盤バネの剛性 $K_{0}$ を求める際には，N值ではな く地盤のせん断弾性波速度から求め, さらに地盤反力の 補正係数を $\alpha_{k}=1.0$ とした.

道路橋示方書では，砂地盤に対する極限支持力に対し てしか杭位置依存性が考慮されていない. しかし，杭基 礎に対する大変形載荷実験結果によれば, 前列の杭に対 してその背面に位置する杭では，剛性も支持力も低いこ $と^{13)}$, 14)，15），このような傾向は粘性土地盤中の杭にも 存在することが指摘されている ${ }^{16)}$. 前列杭の背面に位置 する杭の岡性や極限支持力の值は各種実験によっていろいろ 変化するが，ここでは摡往の大変形載荷夷験結果 ${ }^{\text {(3) }}$, 14)，15) を 参考に，砂質地盤中の杭と同様に粘性土地盤中の杭の場 合にも前列杭では式（10），式（11）によって与えられ る極限支持力 $P_{y}$ ，地盤バネの剛性 $K_{0}$ を，中央および 後列杭ではこれらのそれぞれ $1 / 2$ に低減することとした. 地震力の向きが反転した場合には，後列杭の極限支持力 は $P_{y}$, 地盤バネは $K_{0}$ となり, 中央および前列杭では これらの1/2 になる. したがって, 中央杭ではいずれの 方向に応答しても地盤バネの剛性は $K_{0} / 2$ であるが, 前

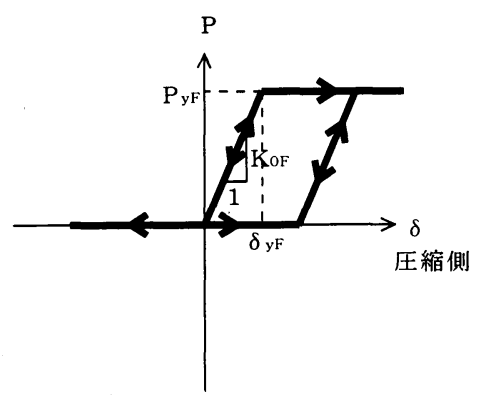

図-13 フーチング前面〜地盤間を結ぶ水平方向バネ の復元力特性

列および後列杭では応答の方向によって地盤バネが $K_{0}$, $K_{0} / 2$ と変化することになる. しかし，ここでは，解析 を簡単にするために図-11に示すように前列および後列 杭の地盤バネはいずれの方向に対しても $K_{0}$ とすること とした.

次に，杭先端の押込みおよび引抜きは，図-12に示す ように完全弾塑性型バイリニアモデルで表し，上下方向 の剛性 $K_{V}$, 押込み耐力 $P_{y c}$, 引抜き耐力 $P_{y T}$ は, 以下 のように与えた

$$
\begin{aligned}
K_{V} & =a \frac{E A}{L} \\
P_{y C}= & \min \left\{N_{p C}, P_{C}\right\} ; P_{y T}=\min \left\{N_{p T}, P_{T}\right\}
\end{aligned}
$$

ここで,

$$
\begin{aligned}
& a=0.031 \frac{L}{D}-0.15 ; P_{C}=q_{d} \cdot A+U \cdot \sum L_{i} \cdot f_{i} \\
& P_{T}=U \cdot \sum L_{i} \cdot f_{i}
\end{aligned}
$$

ここで, $a$ : 鉛直載荷試験より得られる杭の変換係数, $E A / L$ : 杭の軸方向剛性, $N_{p C}$ : 杭の軸圧縮耐力, $P_{C}$ : 地盤力ら決まる杭の極限支持力, $q_{d} A$ : 杭先端に おける極限支持力, $U \cdot \sum L_{i} f_{i}$ : 周面摩擦力, $N_{p T}$ : 杭 の軸引張耐力, $P_{T}$ : 地盤から決まる杭の極限引抜き力 である.

フーチングと地盤を結ぶバネは，図-13に示すように フーチングと周辺地盤バネ間に生じる剥離を考慮したス リップ型のバイリニアモデルで表し，地盤バネの剛性 $K_{0 F}$ は式（11）において杭径 $D$ のかわりにフーチング の前面幅 $B_{e}$ を用い， $\alpha_{k}=1.0$ として求めた ${ }^{1)}$. 極限支 持力 $P_{y F}$ は, 式（10）において, 群杭効果を表す係数 $\eta_{p}$ を1.0 とし， $\alpha_{p}$ を次式による $\alpha_{p F}$ によって置きかえ て求めた ${ }^{1)}$.

$$
\alpha_{p F}=1.0+0.5 \cdot \frac{z}{B_{e}} \leq 3.0
$$



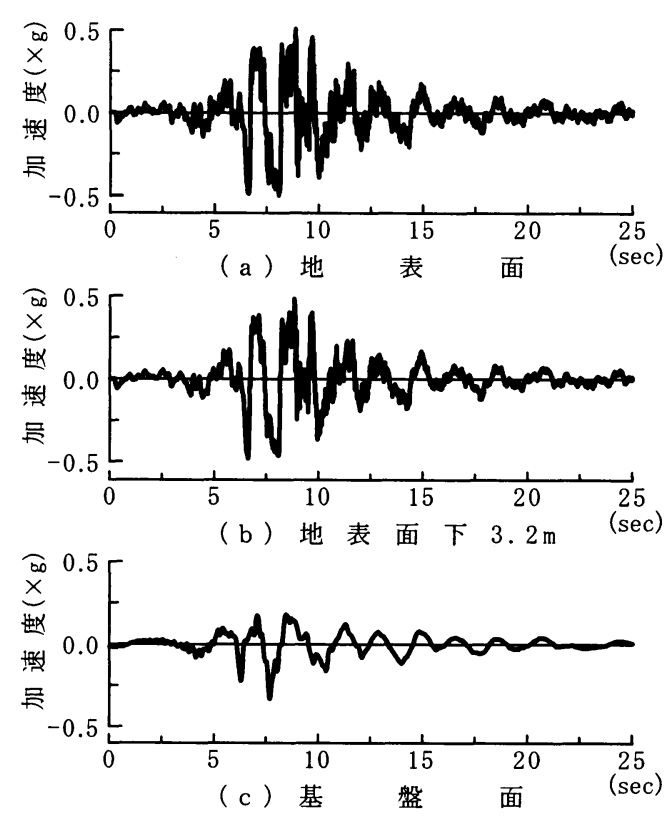

（1）加速度応答
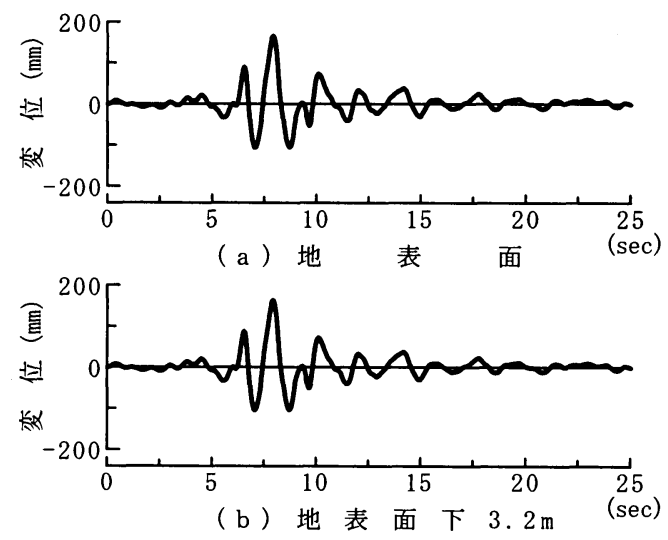

（2）変 位 応答

図-14 地盤の地震応答

ここで, $\quad z$ は地艋面からの媣さである.

\section{（5）減衰のモデル化}

減衰定数は，ゴム支承では $2 \% ，$ 橋脚では $2 \%$ ，杭で は2 $\%$ ，基礎〜地盤間バネでは逸散减衰を見込んで $20 \%$ とした. 地般は非線形復元力特性を見込んでモデル化し ているため，また，フーチングは剛体振動するため，そ れぞれ，減衰定数を0とした. これより，ひずみエネル ギー比例减衰法によりモード減衰定数 $h_{i}$ を求め, 上部 構造の橋軸方向振動が卓越する 1 次振動モード $\left(h_{1}=4.8 \%\right)$ と橋脚躯体や杭体の曲げ変形が卓越する 4 次振動モード $\left(h_{4}=13.4 \%\right)$ に着目して, レイリ一减衰

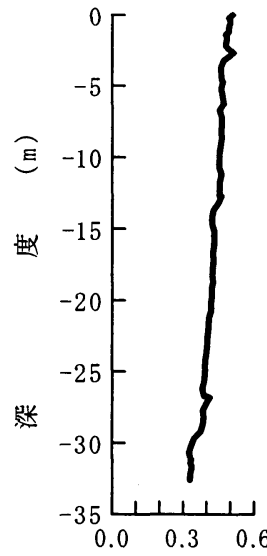

(a) 加速度 $(\times \mathrm{g})$
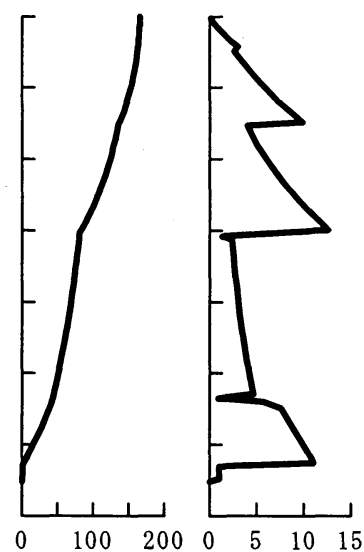

（b）相対変位 (mm) (c) せん断ひずみ $\left(\times 10^{-3}\right)$
図-15 地盤の最大応答分布

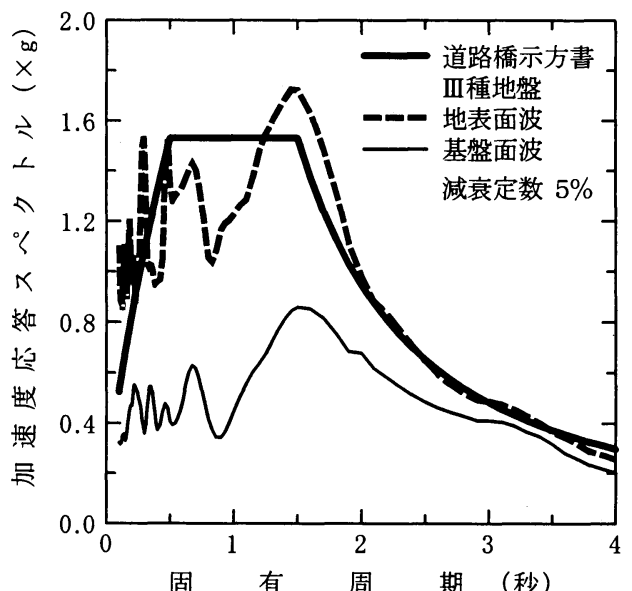

図-16 入力地震動の加速度応答スペクトル
により減衰力をモデル化した.

\section{（6）入力地震動}

入力地震動は耐震設計上の基盤面において与えること とし, 道路橋示方書のタイプエI地震動によるm種地盤上

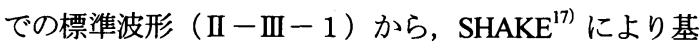
盤面の地震動を求め, これを基盤地震動として地盤モデ ルに作用させて地盤の応答を求めた. 図-14は, このよ うにして求めた地盤の応答を基盤地震動とともに示した ものである. 地盤内の最大応答の分布は図-15のとおり であり, 地表面の最大加速度は $0.5 \mathrm{~g}$ （ $\mathrm{g}$ : 重力加速 度）, 地表面の最大変位は $166 \mathrm{~mm}$ である. 地盤の最大せ 

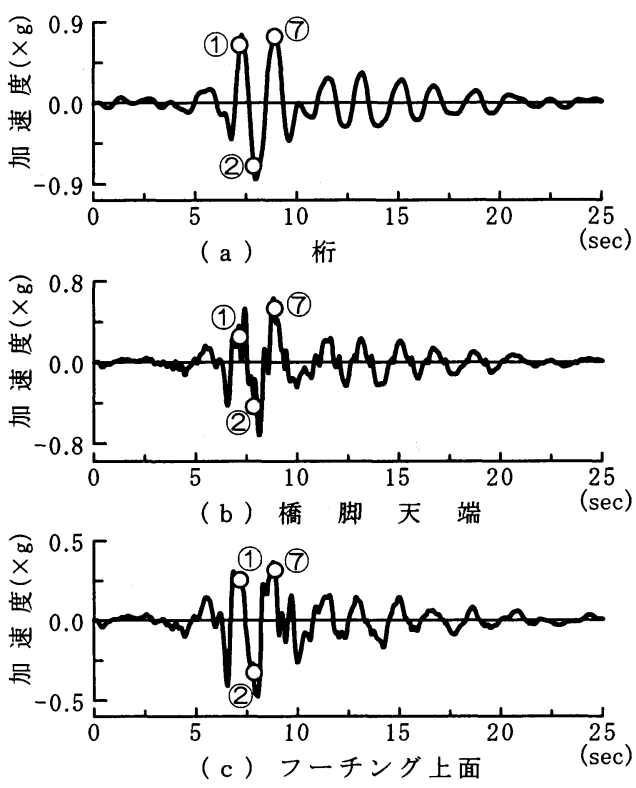

（1）加速度応答
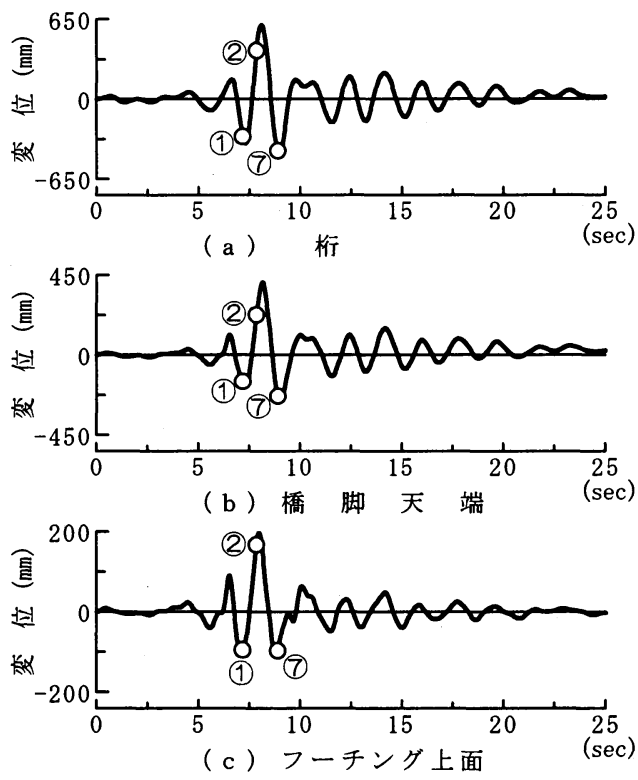

（2）変 位 応答

図-17 橋脚躯体および析の応答

ん断ひずみは地表面下 $15 \mathrm{~m}$ 付近では $1.3 \%$ に達する.この ような大きなせん断ひずみに相当する地盤の剛性や减衰 の評価にはまだいろいろな問題が残されているが, それ についてはここには示さない. 同様の解析結果は他にも いろいろ報告されている ${ }^{18)}$ 。 また，図-16は地表面の地 震動と基盤地震動を減衰定数 $5 \%$ の加速度応答スペクト

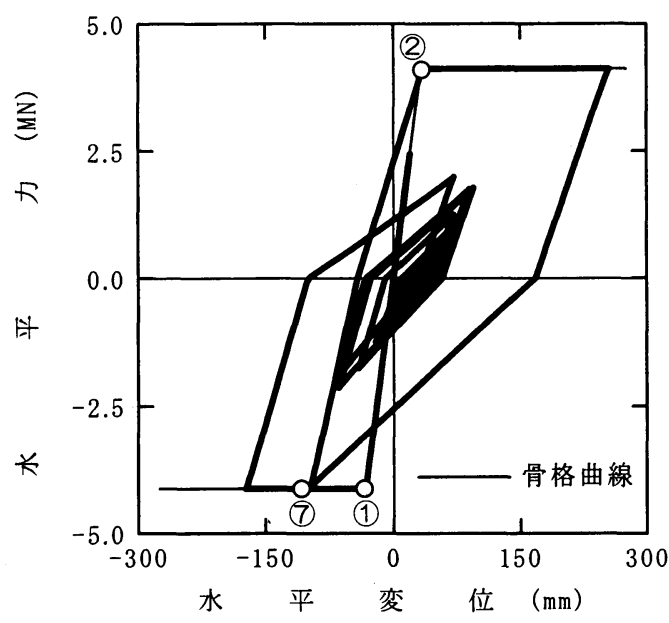

図-18 橋脚天端位置における水平力一水平変位の関係

ルで比較したものである. 図中には参考のために，道路 橋示方書に規定される亚種地盤上の加速度応答スペクト ルも示している. 計算により求めた地表面の地震動は, 本地点の地盤の特性を反映して, 固有周期 1 秒以下では 道路橋示方書のスペクトルよりも小さいが, 固有周期 1.5 秒付近では，道路橋示方書に規定されるスペクトル の1.15倍程度の値となっている.

\section{4. 橋脚と基礎の非線形応答}

\section{(1) 橋脚一析系の応答}

図-7の解析モデルに，図-14の基盤地震動を作用させ た場合の橋脚及び析の応答変位及び応答加速度を図-17 に示す．ここでは，図-4において，橋脚が前列の杭方向 に向かって変位する場合を変位応答の正としている. 図 中には，後述するように橋脚や杭，地盤バネの降伏の順 番を表す番号を示している. (1)，(2)，(7)は，いずれも橋 脚基部が降伏する時刻を示したものである.

図-17によれば, 加速度応答には, 7.27秒, 7.96秒, 8.93秒と 3 つ大きなピークがあり, 最大加速度は析お よび橋脚天端では $0.85 \mathrm{~g}, 0.72 \mathrm{~g}$, フーチング上面では $0.47 \mathrm{~g}$ である. 図-6に示したように, 橋脚の降伏震度 $k_{h p}$ は0.52であるから, 析の応答加速度はこれを約 1.63 倍上回っている. 本来, 减衰がゼロの 1 質点系の応答で は降伏加速度以上の応答加速度は生じないはずであるが, 減衰力が存在する結果, 降伏震度以上の応答加速度が析 に生じている.これについては，6章に示す。

最大変位応答は, 桁および橋脚天端では603mm, 408mm，フーチング上面では196mmとなっている.

図-18は，橋脚の塑性ヒンジ区間中央に生じる曲げモ一 

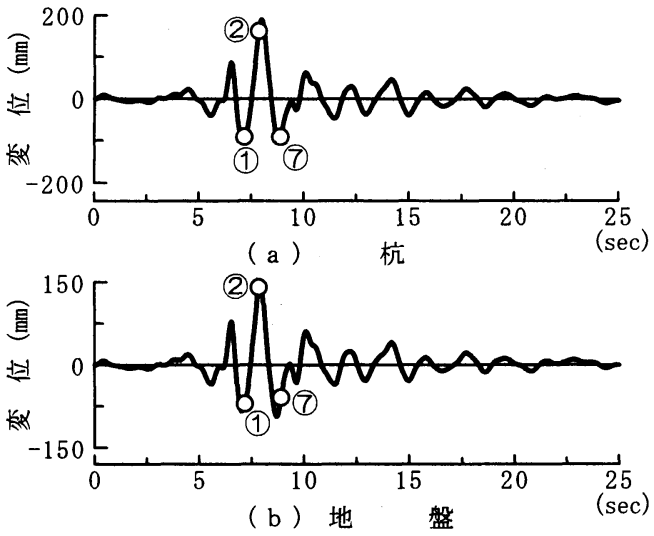

（1）杭 頭（フーチング底面）
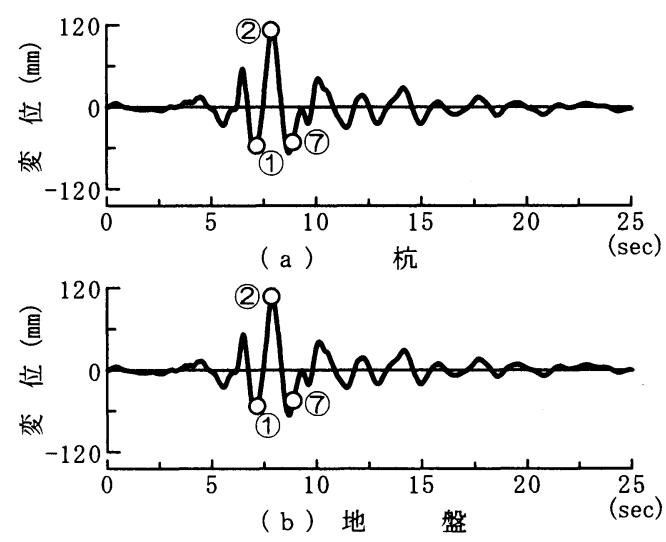

（2）フーチング底面から-7.0mの位置

図-19杭と地盤の変位応答の比較（前列の杭）

メントを橋脚天端（上部構造慣性力作用位置）までの距離 $H_{p}-L_{p} / 2=9.45 \mathrm{~m}$ で除して求めた橋脚天端における水 平力と橋脚の水平変位 $\delta_{P}$ の履歷である. 図-17に示した(1), (2), (7)の3つは, 図-18から求めた橋脚が降伏するときの 時刻である. 橋脚の最大変位応答は255mmであり, 降伏変 位は32.9mmであるから，変位応答塑性率は7.8 となる。

\section{（2）杭の応答}

図-19は，杭頭位置と杭の曲げモーメントが最大とな るフーチング底面から $\pi / 2 \beta=7.0 \mathrm{~m}$ 位置（1/ $\beta$ は杭の 特性値の逆数）における杭と地盤の変位応答を示したも のである. 最大変位は, 杭頭位置では杭が $189 \mathrm{~mm}$ である のに対して地盤が $147 \mathrm{~mm}, \pi / 2 \beta$ の位置では杭が $117 \mathrm{~mm}$ であるのに対して地盤が110mmとなっている. ただし， 杭と地盤の変位は最大となる時刻はわずかに異なってお り, 実際に両者間に生じる最大変位は, 杭頭位置では $74.5 \mathrm{~mm}, \pi / 2 \beta$ の位置では10.6mmである. 図-20は, 杭

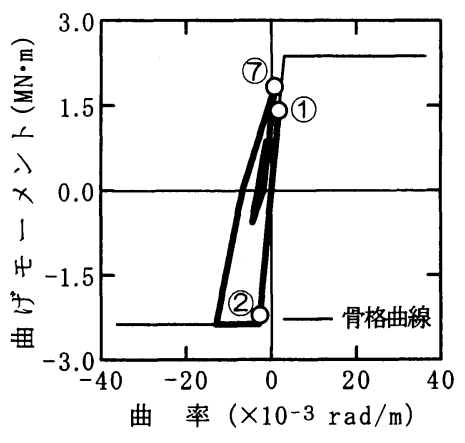

(a) 前 列 の 杭

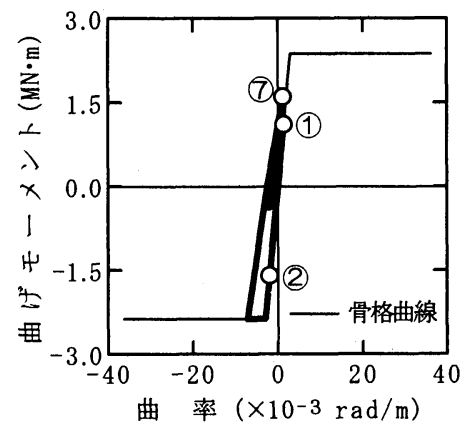

（b）中 央 列 の 杭

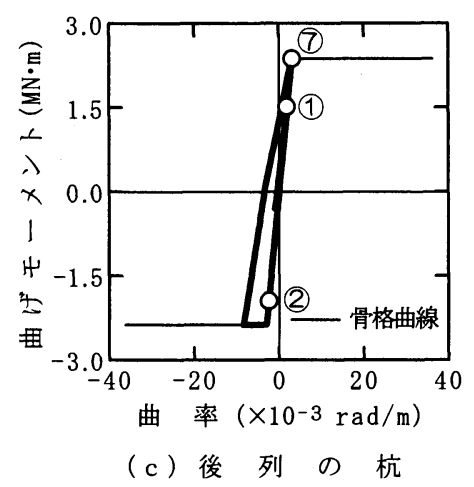

図-20 杭頭部における曲げモーメントー曲率関係

頭部に生じる曲げモーメントと曲率の応答履歷である. 前列の杭, 中央, 後列の各杭とも降伏曲率 $\phi_{F y}$ を上回る 変形が生じており, 最大曲率応答を降伏曲率で除して得 られる曲率応答塑性率は, 前列, 中央, 後列の杭でそれ ぞれ4.4，2.4，2.9である. いずれの杭列も，橋脚が前列 の杭方向に変位し橋脚が 2 回目に降伏（図-18, 図-20中 の(2)）した直後に最初に降伏しており，さらに後列の杭 は, 橋脚が 3 回目の降伏に達する（7） と同時に再度降 伏している. 


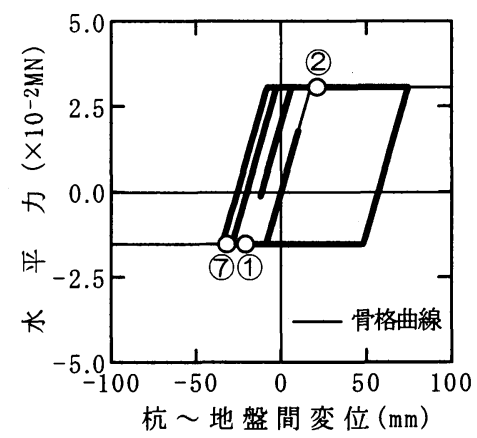

(a) 前 列 $の$ 杭

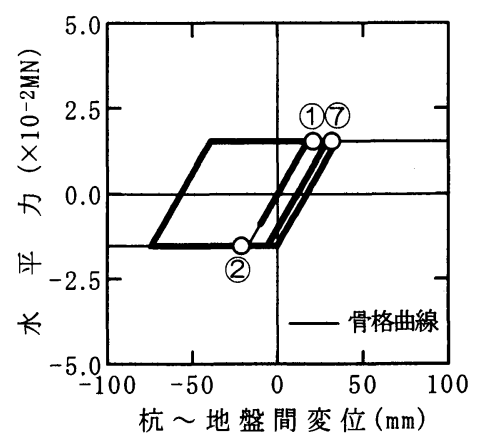

（b）中央列 の 杭

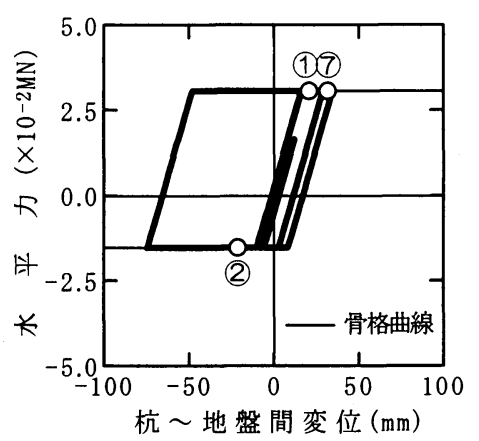

(c) 後 列 の 杭

図-21 杭と地盤間の水平力ー水平変位関係（杭頭位直）

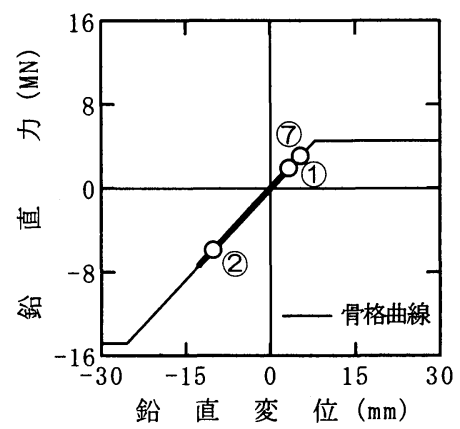

(a) 前 列 $の$ 杭

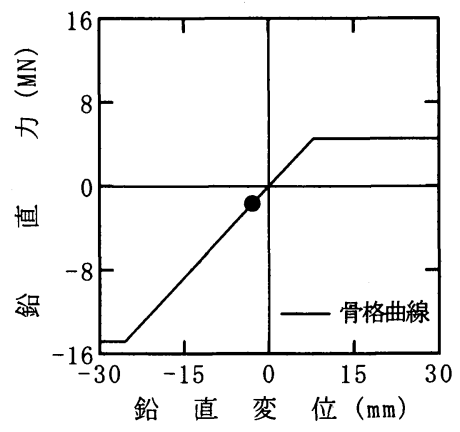

（b）中 央 列 の 杭

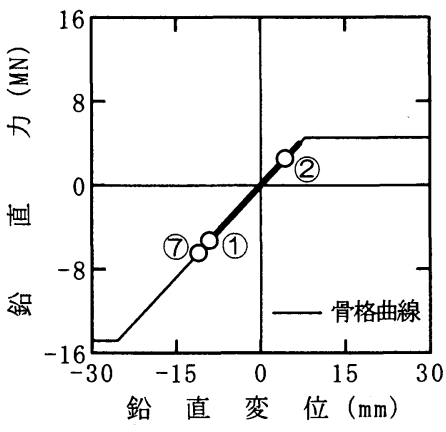

(c) 後 列 $の$ 杭

図-22 杭先端の鉛直力一鉛直変位関倸

図-21は，杭頭位置における基礎〜地盤間の水平バネ に生じる履歴を示したものである. いずれの列において も，地盤バネは降伏しており，前述したように杭〜地盤 間には最大 $74.5 \mathrm{~mm}$ の相対変位が生じている.

一方，図-22は，杭先端における杭〜地盤間の上下方 向バネの履歷を示したものである．鉛直力と鉛直変位は ともに引抜きを正，押込みを負と定義している．いずれ の杭列においても，杭の作用力は押込み耐力，引抜き耐 力の範囲に収まっており, 鉛直力と鉛直変位の関係は線 形域に留まっている. ただし, 対称構造であるから, 中 央の杭には, 地震の作用によって押込みも引き抜けも生 じないため, 鉛直力と鉛直変位の関係は, 死荷重によっ て生じた押込み量から変化していない. 鉛直方向の杭の 変位は, 他の応答と同様に橋脚が 2 回目の降伏に達した 付近（2）で最大となっており，このとき引張り状態に なる後列の杭では, 降伏変位の約 $90 \%$ に相当する $6.8 \mathrm{~mm}$ の変位が生じている.

\section{（3）杭に生じる曲げモーメントに対する地盤変形の影復}

図-23は，杭に生じる最大曲げモーメントの分布を前 列の杭を例に示したものである. 杭に生じる曲げモーメ

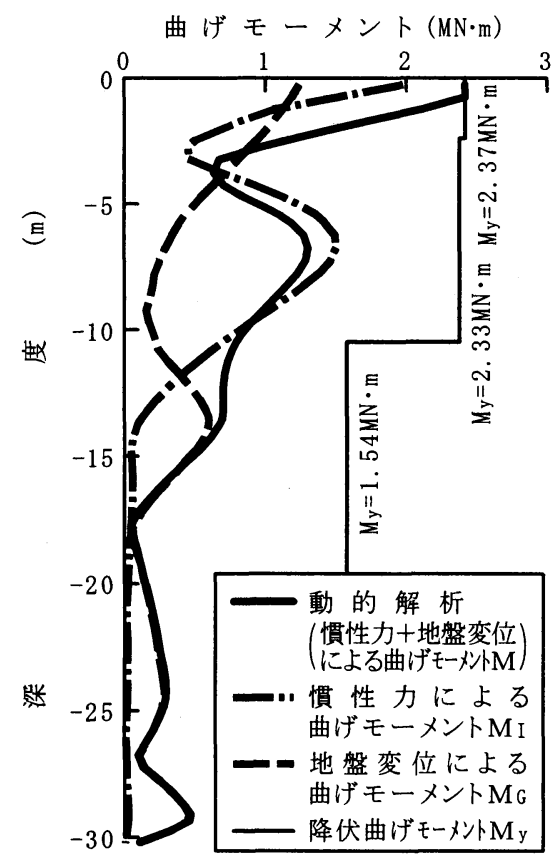

図-23 杭（前列）に生じる曲げモーメント分布 
ントには, 慣性力の影響だけではなく周辺地盤の変形の

影響があることはよく知られている.このため, 杭に生 じる曲げモーメントに対する慣性力の影響と周辺地盤の 影響を分離するために，図一7に示した解析モデルにおい て構造物の質量を全て0として非線形動的解析を行い, これより得られる杭に生ずる曲げモーメント $M_{G}$ を地 盤の変位によって生じる曲げモ一メントと定義する．ま た，これを上述した非線形動的解析によって求めた曲げ モーメント $M$ から差し引くことにより, 構造系の慣性 カによって生じる曲げモーメント $M_{I}$ を次のように求め る.

$$
M_{I}=M-M_{G}
$$

このようにして求めた慣性力による曲げモーメント $M_{I}$, 地盤変位による曲げモーメント $M_{G}$ も図-23に示 している.これによれば, フーチング底面から約 $13 \mathrm{~m}$ (杭径の約 11 倍, $1 / \beta$ の約 3 倍）の範囲では, 構造系の 慣性力による影響が支配的であるが，それより深くなる と地盤変位の影響が支配的となる．杭頭においては慣 性力の影響が支配的とはいえ, 地盤変位の影響を考慮 しないと， $M=2.37 M N \cdot m$ の曲げモーメントを $M_{I}=1.94 M N \cdot m$ と, $18 \%$ 程度過小評価することがわ かる. 同様な結果は, 建築構造物の杭基礎を対象とした 宮本らの研究においても指摘されている ${ }^{19)}$.

\section{(4) 橋脚と杭とのインターアクション}

図-24は慣性力作用位置で表した橋脚からフーチング に対する作用力であり，図-25，図-26はそれぞれ杭頭部 の曲げモーメント，杭先端の鉛直力を示したものである. これらは, ともに，応答が最大となる 4 秒間について示 した結果である. ここには，今まで示してきた橋脚が降 伏するときの時刻(1)，(2)，(7)以外に, 次の状態に達した ときの時刻を示している.

(1)橋脚が後列方向に変位し, 最初に降伏 (7.18秒)

(2)橋脚が前列方向に変位して2回目の降伏 (7.85秒)

(3)前列の杭頭部が降伏 (7.87秒)

(4)後列の杭頭部が降伏 (7.90秒)

(5)中央列の杭頭部が降伏 (7.93秒)

(6)後列の杭頭部が 2 回目の降伏 (8.85秒)

(7)橋脚が後列方向に変位し，3回目の降伏 (8.89秒)

これによれば，橋脚が 2 回目の降伏に達した（2) あ との0.08秒間に前列, 後列, 中央と相次いで杭が降伏し, また, 後列の杭が 2 回目に降伏（6) する0.04秒後に橋 脚が 3 回目の降伏に達することがわかる．減衰力の影響 で，橋脚と杭の降伏が生じる時間は完全には同一ではな いが，時間差はごくわずかであり，実務的には降伏を越 える大きな応答が橋脚に生じると，杭は橋脚と同時に降 伏すると考えても差し支えない.

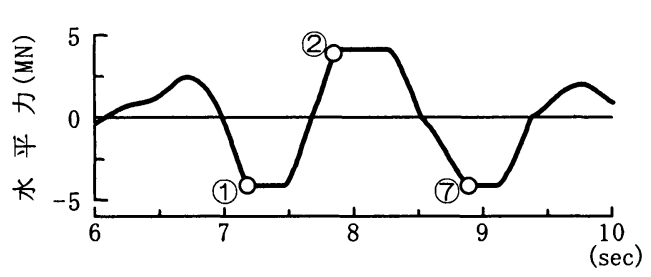

図-24 慣性力作用位置で示した橋脚の作用力
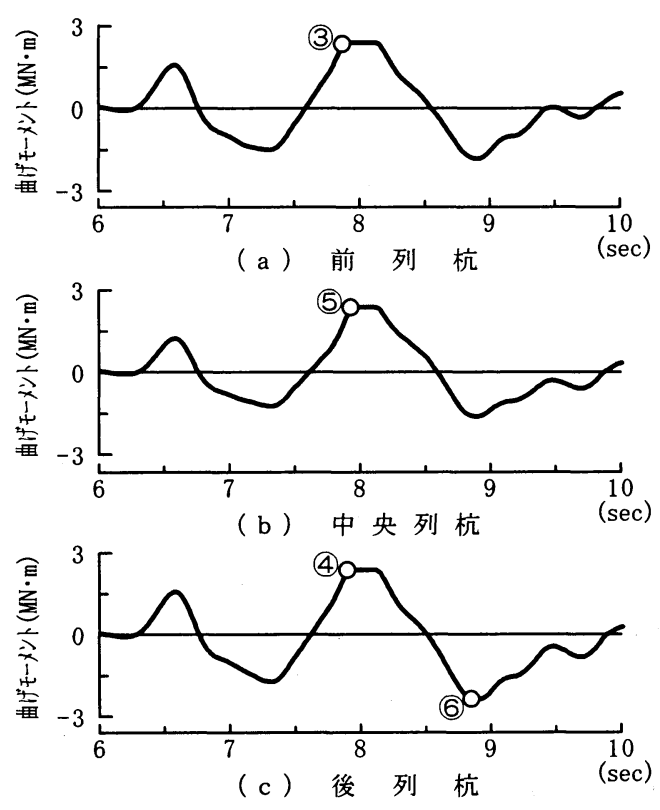

図-25＼cjkstart杭の頭部に生じる曲げモーメント
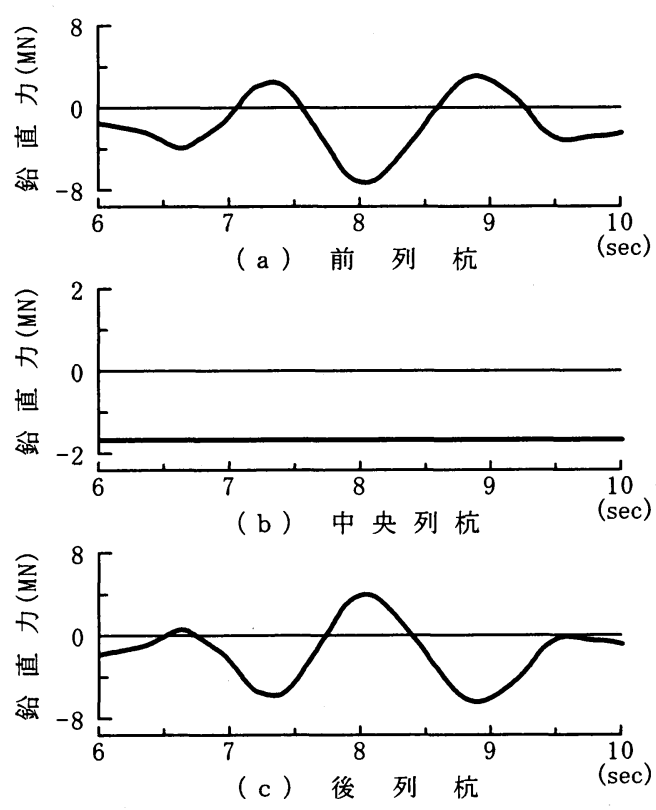

図-26杭の先端に生じる鉛直力 


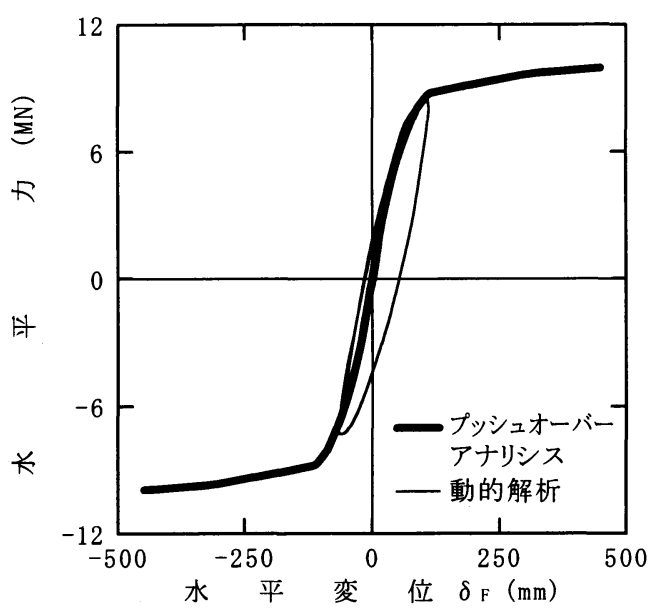

図-27 フーチング底面の水平力および慣性力作用位置 の水平変位（載荷法 I )

\section{5. プッシュオーバーアナリシスによる解析}

以上に示した非線形動的解析による結果が， 2 章に 示した耐震設計結果とどのような関係にあるかを以下に 検討することにする. ただし, 地震時保有水平耐力法に よる耐震設計とは異なり 3 章に示したように動的解析で は, 杭の曲げ履歴をトリリニアモデルからバイリニア型 のTakedaモデルに変化させたこと, 図一11に示したよう に中央列の杭の初期剛性を $K_{0}$ から $1 / 2 K_{0}$ に変化させた こと, 地盤バネの岡性を式（11）で求める際に，地盤の $\mathrm{N}$ 值ではなく地盤のせん断弾性波速度から $k_{h}$ を求めた ことの 3 点が異なっている. このため, 以下では動的解 析に用いた条件で地震時保有水平耐力法により計算し直 した結果と動的解析結果との関連を比較することとする.

まず，両者の比較で最も重要な点は, 橋脚からフー チング底面に作用する水平力および曲げモーメントがど の程度であるかである. このため, これを 2 章に示した プッシュオーバーアナリシスと動的解析法とを比較した 結果が, 図-27である.これによれば，2（3）に示し たプッシュオーバーアナリシスは明らかに，フーチング 底面に作用する水平力と杭基礎の変形によって上部構造 慣性力作用位置に生じる水平変位を過大評価する. これ は, 式（3）, 式（4）では, 橋脚が曲げ降伏すると, これ以上の水平力や曲げモーメントが橋脚からフーチン グには作用しないことが考慮されていないためである.

橋脚の曲げ降伏の影響を見込んでプッシュオーバーア ナリシスを行うためには, 桁, 橋脚, フーチングに対し

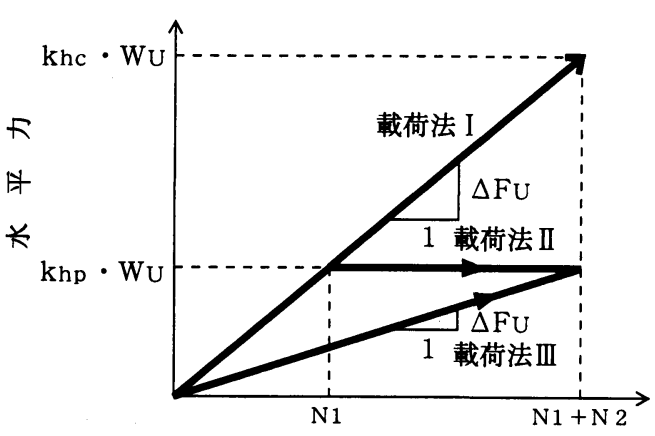

荷重漸增ステップn

（a）㮵による水平力の増分

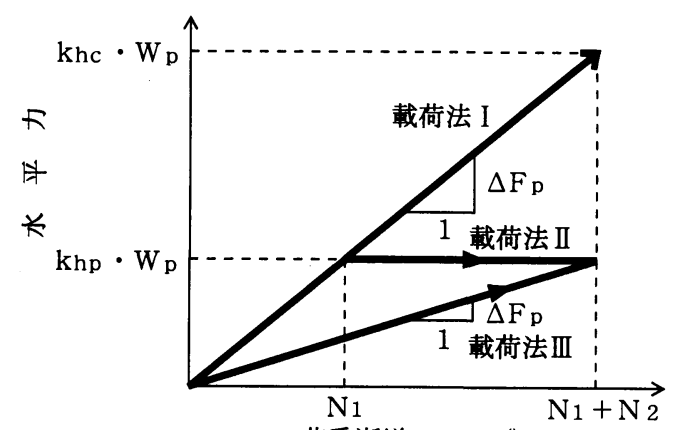

荷重漸增ステッブn

（b）橋脚による水平力の増分

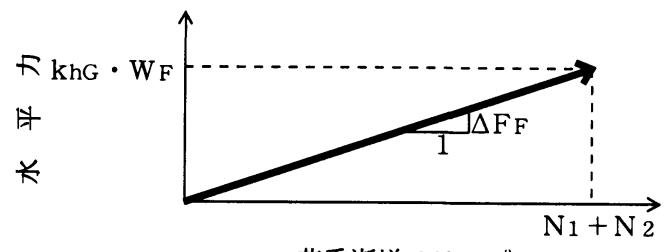

荷重漸增ステッブn

（c）フーチングによる水平力の增分

図-28 フーチング底面に作用させるプッシュオーバー アナリシスによる増分水平力

てどのような経路と順番で地震力を加えるかが重要であ る.このために, ここでは, 次の 2 種類の方法を提案す る. 2 （3）に示した道路橋示方書の方法（以下，これ を載荷法 I と呼ぶ）と区別するために，これらを載荷法 II，IIIと呼ぶこととする.

\section{（1）載荷法 II}

フーチングより上に存在する構造部分の自重を作用 させた状態で, 桁, 橋脚, フーチングに分けて水平力を 荷重漸増法で与える点は，載荷法 I と同じである．しか し, 図-28に示すように, 橋脚が $P_{y}\left(=P_{u}\right)$ で曲げ降伏し た後には，これ以上の慣性力が桁および橋脚からフーチ 
ングには作用しないため，橋脚が降伏するまでの区間と 橋脚が降伏した後の区間に分けて, 増分荷重を評価しよ うというものである. ただし, フーチングに作用させる 地震力は橋脚の降伏の影響を受けないため, 載荷法 I と 同じとする.

いま，橋脚が降伏するまでの区間を $N_{1}$ 分割，橋脚が 降伏した後の区間を $N_{2}$ 分割すると, 第 $n$ 回めの載荷ス テップにおいて，フーチングに作用させる増分水平力 $\Delta F_{F}$ は, 式 (3) と同様に次式のように与えられる.

$$
\Delta F_{F}=\frac{k_{h G} \cdot W_{F}}{N_{1}+N_{2}}
$$

一方, 桁および橋脚に作用させる第 $n$ 回めの増分水 平力 $\Delta F_{U}$ および $\Delta F_{p}$ は,

$$
\begin{gathered}
\Delta F_{U}= \begin{cases}\frac{k_{h p} \cdot W_{U}}{N_{1}} & 1 \leq n \leq N_{1} \\
0 & N_{1}+1 \leq n \leq N_{1}+N_{2}\end{cases} \\
\Delta F_{p}= \begin{cases}\frac{k_{h p} \cdot W_{p}}{N_{1}} & 1 \leq n \leq N_{1} \\
0 & N_{1}+1 \leq n \leq N_{1}+N_{2}\end{cases}
\end{gathered}
$$

ここで, $k_{h p}$ は橋脚の降伏震度であり, 式 $(2)$ より,

$$
k_{h p}=\frac{P_{u}}{W}
$$

したがって，この増分水平力によって第 $n$ 回目の載 荷によりフーチング底面に作用する水平力 $F_{F 0}$ および モーメント $M_{F 0}$ は以下のように与えられる.

$F_{F 0}= \begin{cases}\frac{n \cdot k_{h p}}{N_{1}}\left(W_{U}+W_{p}\right)+\frac{n \cdot k_{h G}}{N_{1}+N_{2}} \cdot W_{F} & \\ k_{h p}\left(W_{U}+W_{p}\right)+\frac{n \cdot k_{h G}}{N_{1}+N_{2}} \cdot W_{F} & 1 \leq n \leq N_{1} \\ N_{1}+1 \leq n \leq N_{1}+N_{2}\end{cases}$

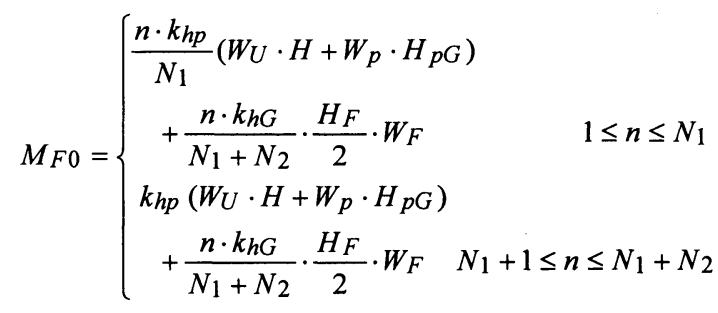

\section{（2）載荷法III}

載荷法 II では，橋脚が降伏する前と降伏した後に分け て増分荷重を与えるが，全区間を同じ荷重増分で解析し ようという方法が載荷法正である。いま， $N_{1}+N_{2}=N$ とおき, 全区間を $N$ 分割するとすれば, 桁, 橋脚, フーチングに作用させる増分水平力は,

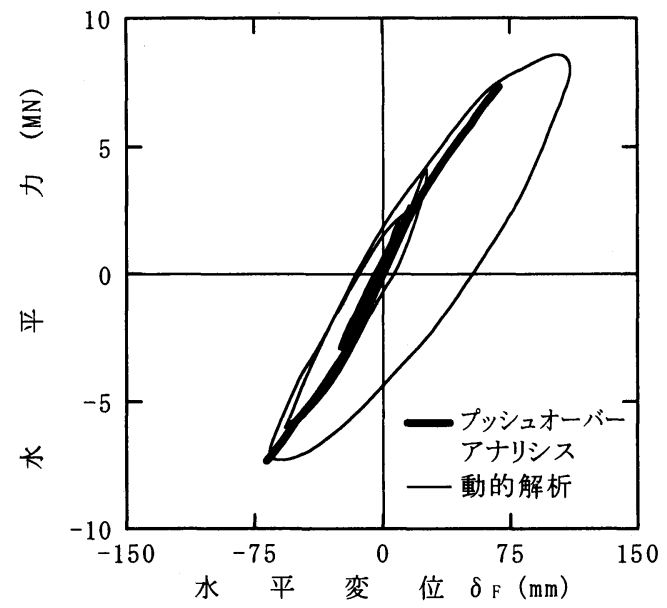

（a）載 荷 法 II

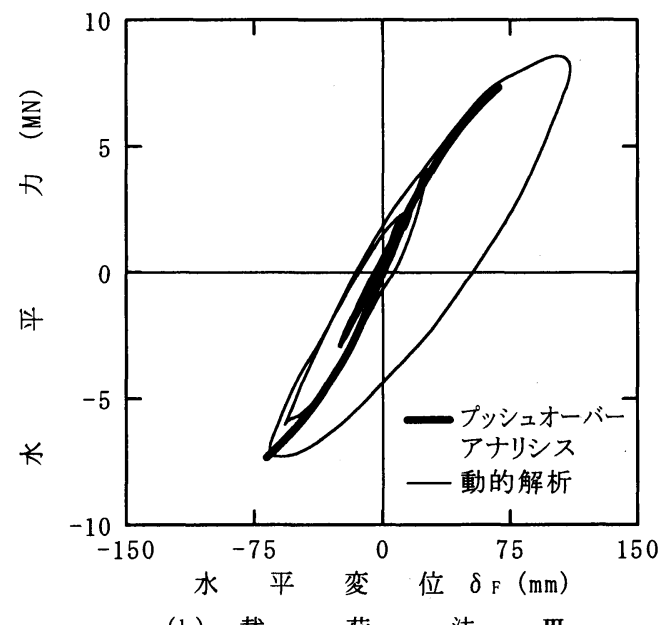

（b）載荷 法 III

図-29 フーチング底面の水平力および慣性力作用位置 の水平変位

$$
\Delta F_{U}=\frac{k_{h p} \cdot W_{U}}{N} ; \Delta F_{p}=\frac{k_{h p} \cdot W_{p}}{N} ; \Delta F_{F}=\frac{k_{h G} \cdot W_{F}}{N}
$$

この増分水平力によって, 第 $n$ 回目の載荷によりフーチ ング底面に作用する水平力 $F_{F 0}$ およびモーメント $M_{F 0}$ は,

$$
\begin{aligned}
& F_{F 0}=\frac{n \cdot k_{h p}}{N}\left(W_{U}+W_{p}+\gamma \cdot W_{F}\right) \\
& M_{F 0}=\frac{n \cdot k_{h p}}{N}\left(W_{U} \cdot H+W_{p} \cdot H_{p G}+\frac{1}{2} \cdot \gamma \cdot W_{F} \cdot H_{F}\right)
\end{aligned}
$$

ここで, $\gamma=k_{h G} / k_{h p}$ である.

載荷法II， IIIによりフーチング底面の $F_{F 0} \sim \delta_{F}$ の関 
倸を求め, これを非線形動的解析結果と比較した結果が 図-29である．載荷法 II，IIIにおける載荷経路はそれ程 大きく解析結果に影響しないことがわかる．しかし，図 -24に示した橋脚の作用力からわかるように，橋脚が降 伏するまでの区間と橋脚が降伏した後の区間に分けて, 増分荷重を評価する載荷法 Iの方が，載荷経路としては 動的解析結果との一致度は高い. しかし, 載荷法IIを用 いても，なおフーチング底面に生じる水平力と曲げモー メントは動的解析結果よりも小さくなっている. この原 因としては, プッシュオーバーアナリシスでは, 橋脚の 降伏耐力 $P_{y}\left(=P_{u}\right)$ 以上の水平力は橋脚からフーチング に作用しないと考えているが，実際には，これに加えて 減衰力の寄与がある. 今, これを検討するために, 図一7 のモデルを用い，フーチング底面に作用する水平力 $F_{F}$ および曲げモーメント $M_{F}$ を次のように求めることに した.

$$
\left.\begin{array}{l}
F_{F}(t)=\sum_{i=1}^{n F} m_{i}\left\{\ddot{u}_{i}(t)+\ddot{z}_{g}(t)\right\} \\
M_{F}(t)=\sum_{i=1}^{n F} m_{i}\left\{\ddot{u}_{i}(t)+\ddot{z}_{g}(t)\right\} \cdot h_{i}
\end{array}\right\}
$$

ここで, $m_{i}, \ddot{u}_{i}(t)$ は節点 $i$ における質量および相対加速 度, $\ddot{z}_{g}(t)$ は入力地震動加速度, $h_{i}$ はフーチング底面か ら節点 $i$ までの距離である． $n_{F}$ はフーチング底面の節 点番号で, 図-7のモデルでは, $n_{F}=10$ である.このよ うにして, $F_{F}(t), M_{F}(t)$ の最大值 $F_{F \max }, M_{F \max }$ を 求めると 8.64MN, $78.34 M N \cdot m$ となる. 橋脚の降伏耐 力 $P_{y}$ とフーチングの慣性力 $k_{h G} \cdot W_{F}$ によってフーチン グ底面に生じる水平力 $F_{F 0}$ と曲げモーメント $M_{F 0}$ は, 式（21）で与えられるため，実際にフーチング底面に作 用する水平力 $F_{F}$ と曲げモーメント $M_{F}$ との比を次式の ように定義すると，

$$
\begin{aligned}
& \alpha_{F}=\frac{F_{F \max }}{F_{F 0}}=\frac{8.64 M N}{7.33 M N}=1.18 \\
& \alpha_{M}=\frac{M_{F \max }}{M_{F 0}}=\frac{78.34 M N \cdot m}{56.13 M N \cdot m}=1.40
\end{aligned}
$$

となる．したがって，18\%，40\%の増加がフーチング底 面に作用するそれぞれ水平力，曲げモーメントに対する 减衰力の寄与ということになる.

式 (25)，式（26）による割り増し係数 $\alpha_{F}, \alpha_{M}$ を 考慮して, 載荷法匹によりフーチング底面の水平力〜上 部構造慣性力作用位置に生じる水平変位 $\delta_{F}$ の関倸を求 めた結果が図-30である. 図-29に比較して, プッシュ オーバーアナリシスと動的解析結果との一致度は大幅に 向上している. ただし，フーチングの変形による上部構

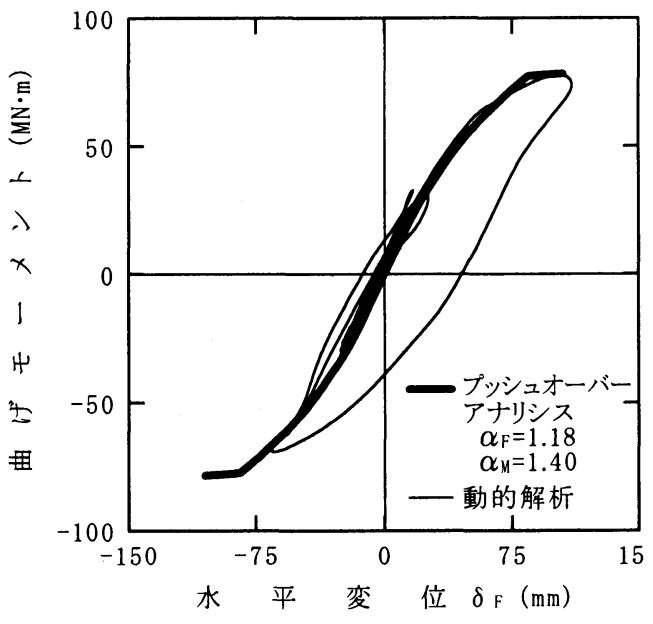

図-30 フーチング底面の水平力〜慣性力作用位置の 水平変位の関係 $\left(\alpha_{F}=1.18, \alpha_{M}=1.40\right)$

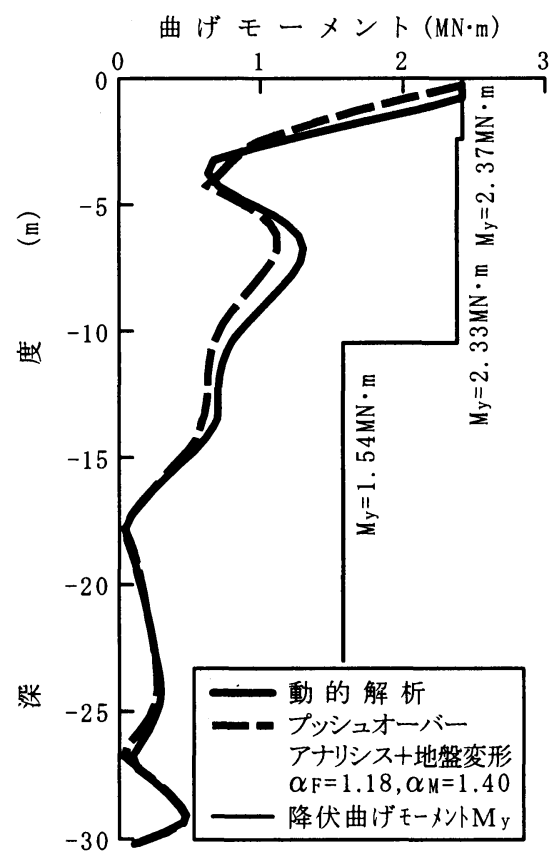

図-31 杭（前列）に生じる曲げモーメント分布

造慣性力作用位置の水平変位 $\delta_{F}$ が負の場合には, プッ シュオーバーアナリシスは動的解析結果よりも大きな応 答を与える. これは, 動的解析の最大応答変位が正側に は110mmであるのに対して負側には67mmと小さいが， これは4（4）に示したように, 入力地震動と構造系の 特性の両者から決まったものであり, 入力地震動の位相 を反転させて，同じ解析を行えば，上記とは反対に負側 
表-2 動的解析とプッシュオーバーアナリシスによる

慣性力作用位置における水平変位の比較

\begin{tabular}{|c|c|c|c|}
\hline \multirow{2}{*}{ 杭の状態 } & \multirow{2}{*}{$\begin{array}{l}\text { 動的 } \\
\text { 解析 }\end{array}$} & \multicolumn{2}{|c|}{ プッシュオーバーアナリシス } \\
\hline & & $\begin{array}{l}\alpha_{\mathrm{F}}=1.18 \\
\alpha_{\mathrm{M}}=1.40\end{array}$ & $\begin{array}{l}\alpha_{\mathrm{F}}=1.30 \\
\alpha_{\mathrm{M}}=1.30\end{array}$ \\
\hline (3)前列の杭の頭部が降伏 & $57.0 \mathrm{~mm}$ & $64.3 \mathrm{~mm}$ & $62.0 \mathrm{~mm}$ \\
\hline (4)後列の杭の頭部が降伏 & $66.0 \mathrm{~mm}$ & $70.2 \mathrm{~mm}$ & $67.3 \mathrm{~mm}$ \\
\hline $\begin{array}{l}\text { (5)中央列の杭の頭部が } \\
\text { 降伏 }\end{array}$ & $74.4 \mathrm{~mm}$ & $74.1 \mathrm{~mm}$ & $70.9 \mathrm{~mm}$ \\
\hline
\end{tabular}

の方が正側よりも大きくなる．したがって，プッシュ オーバーアナリシスでは, 動的解析のうち, 最大応答を いかに正確に表わせるかが重要であり，こうした観点か らみると図-30では, プッシュオーバーアナリシスの精 度は高いと言うことができる.

プッシュオーバーアナリシスによって求めた杭に生 じる曲げモーメントと動的解析結果との比較を前列杭に 対して示した結果が図-31である. 図-24に示したように 地盤変形の影響は無視できないため, ここでは, 動的解 析より得られた地盤の最大変位を杭〜地盤間のバネを介 して杭に作用させた後, プッシュオーバーアナリシスを 行った. なお, 杭基礎の地震時保有水平耐力法に用いる 周辺地盤の変位を求めるための実用的な方法の開発は, 今後詳細に検討していかなければならない.プッシュ オーバーアナリシスの結果は, 全体として動的解析結果 を良く表していると言うことができる. また，4（4） に示した(1)〜(7)の主要な塑性化の進展状況の中から, 橋 脚の塑性化 (1), (2)，(7)）と地震力の向きが反転し, 後 列杭が 2 回めに塑性化した場合 (6) を除く (3), (4), (5) の段階で杭が塑性化した順番と, その時のフーチングの 変形により上部構造慣性力作用位置に生じる水平変位 $\delta_{F}$ を動的解析結果と比較した結果が表-2である. ここ には, 後述する $\alpha_{F}=\alpha_{M}=1.3$ とした場合の結果も示し ている. これによれば, 杭の塑性化が前列 $\rightarrow$ 後列 $\rightarrow$ 中央 列と進展する順番や，その時の水平変位 $\delta_{F}$ もプッシュ オーバーアナリシスによってよく解析できていることが わかる.

\section{6. 減衰力によるフーチング底面作用力の割り増し の評価}

以上に示したように，式（25），式（26）によ る $\alpha_{F}, \alpha_{M}$ の割り増し係数を考慮すれば, プッシュ オーバーアナリシスは非線形動的解析によって求めた フーチング底面の作用力や杭に生じる曲げモーメント を精度良く与えることができる，しかし，式（25），

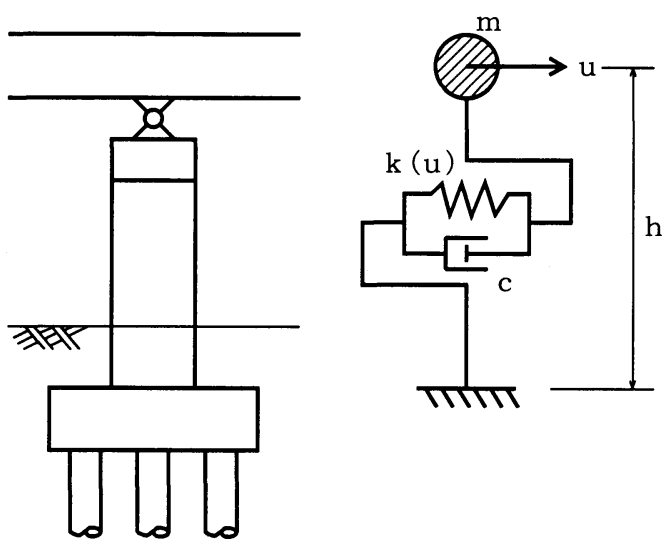

図-32 减衰力の影響を検討した解析モデル

式 (26) により $F_{F}(t), M_{F}(t)$ を求めるためには, 非線 形動的解析を行なわなければならず, 地震時保有水平 耐力法の枠組みの中でプッシュオーバーアナリシスを 行うメリットが発揮されない。このため, 式 (26), 式 (25) による $F_{F}(t), M_{F}(t)$ を推定することを目的と して,ここでは図-32に示すようにTakeda型の剛性低下 型モデルで支持された 1 自由度系にモデル化した橋の 応答を解析する. ここで, 道路橋示方書に従い質点の 質量 $m$ は, 式 (2) から求めた.

図-32のモデルでは，式（24）から橋脚基部に作用す る水平力は,

$$
F_{F}(t)=-c \dot{u}(t)-f_{R}(t)=m\left\{\ddot{u}(t)+\ddot{z}_{g}(t)\right\}
$$

ここで, $\dot{u}(t), \ddot{u}(t)$ は 1 自由度系の相対速度, 相対加速 度であり, $\ddot{z}_{g}(t)$ は入力地震動加速度, $f_{R}(t)$ はTakeda モデルによって表した橋脚の復元力, $c$ は減衰係数であ る. 式 (27) で与えられる $F_{F}$ の最大值と橋脚の降伏耐 カ $P_{y}$ との比として, 式 (25) の $\alpha_{F}$ は次式によって与 えられる.

$$
\alpha F=\frac{F_{F_{\text {max }}}}{P_{y}}=\frac{\left|m\left\{\ddot{u}(t)+\ddot{z}_{g}(t)\right\}\right|_{\text {max }}}{P_{y}}
$$

この $\alpha_{F}$ を高架橋を対象として解析することとした.

解析対象としたのは, 橋脚高さ $h$ を $7,11,15 \mathrm{~m}$ の 3 種 類, 支間長を $30,40,50 \mathrm{~m} の 3$ 種類に, 変化させた合計 9 種類の単柱式RC橋脚で支持された高架橋である. 降 伏剛性を用いた固有周期は，0.33〜0.65秒となる.これ らに対して，それぞれ，道路橋示方書のタイプ I , II の 標準波形 $\left(\mathrm{I}-1 \sim \mathrm{III}-1\right.$ の 6 波形 ${ }^{2)}$, 兵庫県南部地 震で観測された神戸海洋気象台記録NS成分 ${ }^{20)}$, JR鷹取駅 記録EW成分 ${ }^{21}$ ，東神戸大橋記録N12W成分，ノースリッ 


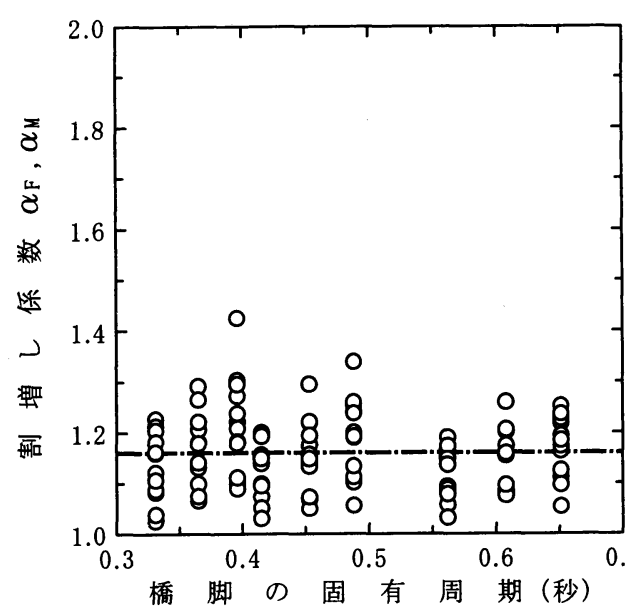

(a) 減衰定数 $\mathrm{h}=0.05$ の場 合

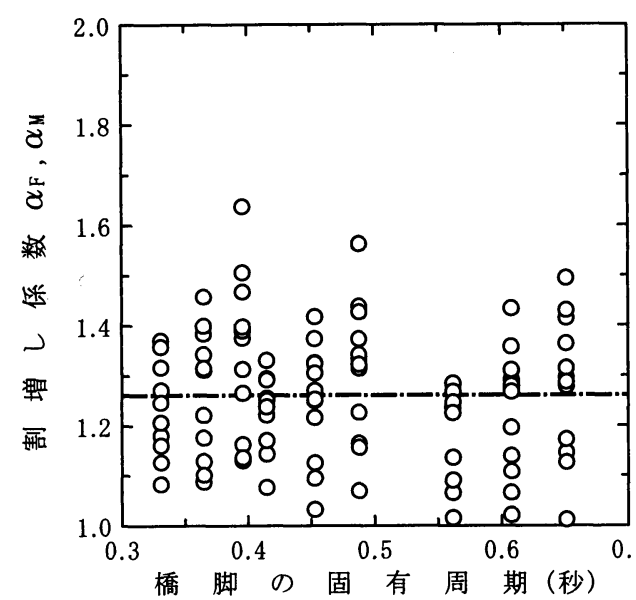

(b) 減衰定数 $h=0.10$ の場 合

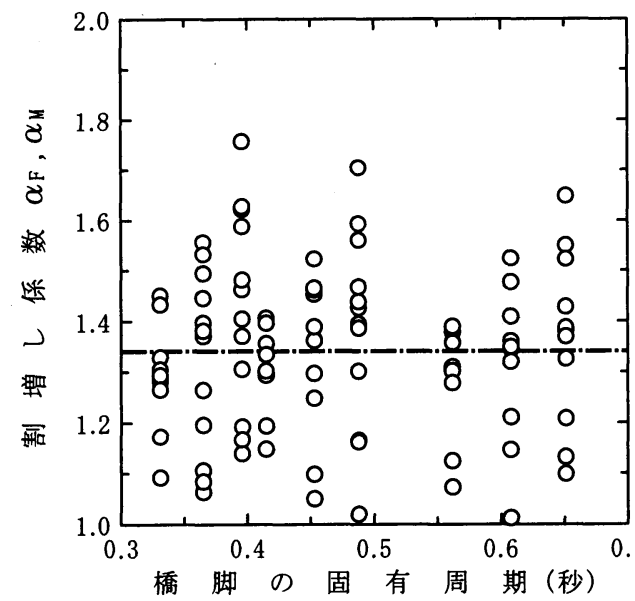

(c) 減衰定数 $\mathrm{h}=0.15$ の場合

図-33 減衰力による割増し係数

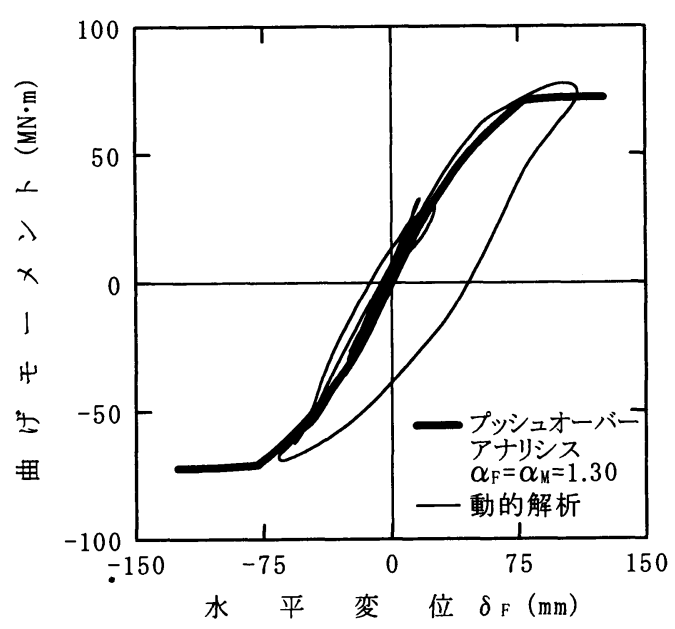

図-34 フーチング底面の水平力〜慣性力作用位置の 水平変位の関係 $\left(\alpha_{F}=\alpha_{M}=1.30\right)$

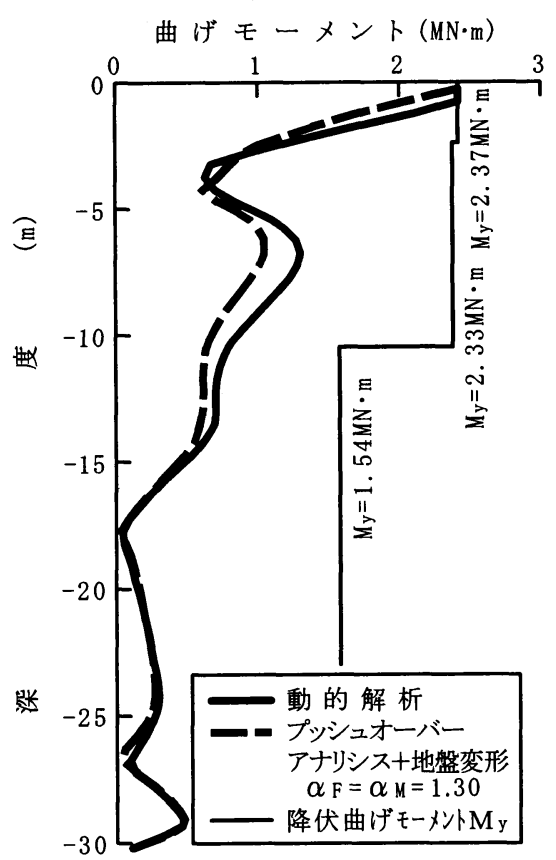

図-35 杭（前列）に生じる曲げモーメント分布

ジ地震で観測されたSylmar駐車場記録EW成分22), 釧路 沖地震で観測された釧路気象台記録EW成分 ${ }^{23)}$ ，今回の 解析より求められた地表面の地震動 (図-14参照) の合 計12波形を作用させた．また，フーチング底面に作用す る地震力への減衰力の影響を検討する際に考慮しなけれ ばならない減衰効果としては, 橋脚とゴム支承の減衰,

基礎〜地盤間の逸散減衰がある３（5）に示したよう に, 図一7における解析モデルの主要な振動モードでは, 
モード減衰定数が約 $0.05 〜 0.13$ となっており，これらは ともに，橋脚とゴム支承に与えた減衰定数よりも大きく， 逸散減衰の寄与が大きいことがわかる．ここでは，図一 32に示すように橋を 1 自由度系にモデル化したので，逸 散减衰の効果を减衰力としてモデル化する必要がある. ここでは, 橋全体系の隇衰定数を $0.05,0.1,0.15$ と 3 種 類に変化させ， 1 自由度系であることから剛性比例型減 衰により減衰力をモデル化した. 合計 $9 \times 12 \times 3=324$ 種 類の解析から求めた $\alpha_{F}$ を図-33に示寸. 同一の高架橋 でも, 入力地震動や減衰定数によって $\alpha_{F}$ は大きく異な り, 例えば，減衰定数を 0.1 とした場合を例にとれば, 固有周期が0.40秒の橋では, $1.15 \sim 1.65$ の範囲で $\alpha_{F}$ が変 化する. ここで解析対象とした範囲内では $\alpha_{F}$ は固有周 期によって顕著に変化しないため, 9 橋 $\times 12$ 波形に対す る $\alpha_{F}$ の平均值を求めると, 減衰定数 $0.05,0.10,0.15$ の場合に，それぞれ1.16，1.26，1.34 となる.一般に, 固有周期が $0.33 \sim 0.65$ 秒の範囲にある高架橋では, 減衰 定数は 0.1 程度であることから,$\alpha_{F}=\alpha_{M}=1.30$ とし てプッシュオーバーアナリシスによりフーチング底面に おける水平力〜慣性力作用位置に生じる水平变位 $\delta_{F}$ の 関係や杭に生じる曲げモーメントを求めた結果が図-34, 図-35である. プッシュオーバーアナリシスの結果は, 動的解析結果とよく一致しており，これは図-30や図-31 に示した結果と比較してもそれ程抙色がない. また，前 出の表-2には， $\alpha_{F}=\alpha_{M}=1.30$ とした場合に杭の塑性 化が生じる順番とその時のフーチングの変形により上部 構造慣性力作用位置に生じる水平変位 $\delta_{F}$ も示している. プッシュオーバーアナリシスによる水平変位 $\delta_{F}$ は, 動 的解析による水平変位の $\pm 10 \%$ 以内の誤差に収まってお り，実務上十分な精度を有している.

\section{7. 結 論}

$\mathrm{R}$ C橋脚で支持された基礎一橋脚一桁系を対象とし て，橋脚および杭基礎の非線形応答特性，橋脚から基礎 に作用する地震力の特性を明らかにした. 本解析で得ら れた結果をまとめると次のとおりである.

（1）杭に生ずる曲げモーメントを式（16）のように, フーチングから上の構造系の慣性力によって生じる曲げ モーメント $M_{I}$ と地盤の変形によって生じる曲げモーメ ント $M_{G}$ に分離すると, $M_{I}, M_{G}$ は全曲げモーメント のそれぞれ $82 \%, 18 \%$ となる. 地盤の変形の影響を無視 することは杭基礎の設計上，曲げモーメントを過小評価 することになる.

（2）プッシュオーバーアナリシスでは，荷重漸増させ る経路や組み合わせが重要であり, 式（4）による載荷 法 I は明らかにフーチング底面に作用する地震力を過大
に与える. 式 (21) による載荷法II と式（23）による載 荷法而の違いは大きいものではないが, 載荷法川の方が 動的解析結果との一致度が高い.

（3）降伏耐力 $P_{y}$, 降伏曲げ耐力 $M_{y}$ を有する橋脚で 支持された構造系において, 実際に橋脚からフーチング に伝達される水平力, 曲げモーメントは $P_{y}, M_{y}$ に式 （25），式（26）による係数 $\alpha_{F}, \alpha_{\mathrm{M}}$ を乗じた值であり, $P_{y}, M_{y}$ を橋脚からフーチングに作用する地震力とみな すことは，杭基礎に対する地震力を過小評価する.

（4）式 (25)，式 (26) による係数 $\alpha_{F}, \alpha_{\mathrm{M}}$ を用いて フーチング底面に作用する水平力, 曲げモーメントを プッシュオーバーアナリシスによって求めると, 非線形 動的解析の結果と良く一致する. また，地盤の変形を考 慮すれば, プッシュオーバーアナリシスで求めた杭の曲 げモーメントも非線形動的解析結果とよく一致する.

（5）フーチング底面に作用する地震力の割り増し係数 $\alpha_{F}$ を簡易に算定するため, 図-32に示したモデルを提 案した.これによれば典型的な高架橋では, 入力地震動 が固有周期, 减衰定数によって $\alpha_{F}=1.0 \sim 1.8$ と広範囲 にばらつくが, 本例では $\alpha_{F}=1.3$ としてプッシュオー バーアナリシスにより解析したフーチング底面の水平力 および曲げモーメントは, 非線形動的解析結果と良く一 致する.

（6）以上より，減衰力によるフーチング底面に作用す る地震力の割り増しと, 地盤の変形を考慮し, 載荷法II に基づいてプッシュオーバーアナリシスによって解析す れば, 杭全体の降伏耐力, 終局耐力, これらの時の変位 等, 地震時保有水平耐力法に必要な特性を実用的に十分 な精度で算定することができる.

\section{参考文献}

1）（社）日本道路協会: 道路橋示方書・同解説IV下部構造編， V而震設計編, 1996.

2）（社）日本道路協会 : 道路橋の耐震設計に関する資料, 1997.

3) Ciampoli, M. and Pinto, P.E. : Effects of Soil -Structure Interaction on Inelastic Seismic Response of Bridge Piers, Journal of Structural Engineering, ASCE,Vol.121, No.5, pp.806-814, May. 1995.

4) Ciampoli, M. and Pinto, P.E. : Effects of Soil -Structure Interaction on the Inelastic Response of Structures, Proc. of the 2nd International Workshop on the Seismic Design of Bridges, Vol.1,pp.298309,1994.

5）笹田修司, 平尾潔, 沢田勉, 成行義文, 三上卓 : 基礎との 相互作用が強震時 R C 橋脚降伏強度比の所要に及ぼす影 響, 構造工学論文集, 土木学会, Vol.42A, pp.615-626, 1996.

6）永田和寿，渡邊英一，杉浦邦征：基礎一構造物系の非線形 
動的相互作用に関する研究, 構造工学論文集, 土木学会, Vol.42A, pp.593-602, 1996.

7 ）鈴木基行, 浅井聡史, 砂金伸治, 武田篤史, 藤原稳 : R C ラーメン高架橋の地震応答に及ぼす地盤特性の影響, 構 造工学論文集, 土木学会, Vol.42A, pp.603-614, 1996.

8) Priestley, M.J.N., Seible, F. and Calvi, G.M. : Seismic Design and Retrofit of Bridges, John Wiley \& Sons, Inc., 1996. U島一彦 監訳 : 橋梁の耐震設計と而震補強，技報堂，1998. )

9) Takeda, T., Sozen, M.A. and Nielsen, N.M. : Reinforced Concrete Response to Simulated Earthquakes, Journal of the Structural Division, ASCE,Vol.96, No.ST12, pp.2557-2573, 1970.

10) Hardin, B.O. and Drenevitch, V.P. : Shear Modules and Damping in Soils:Design Equation and Curves, Journal of the Soil Mechanics and Foundations Division, ASCE,Vol.98, SM7, pp.667-692, July. 1972.

11）岩崎敏男, 龍岡文夫, 高木義和 : 地盤の動的変形特性に関 する実験（II）一広範囲なひずみ領域における砂の動的 変形特性一, 土木研究所報告 第153号, 1980.

12）岩崎敏男, 常田賢一, 吉田精一: 沖積粘性土の動的変形特 性一せん断剛性率のヒズミ依存性一, 土木研究所資料 第1504号, 1979.

13）岡原美知夫, 木村嘉富, 高木繁, 大堀裕康 : 群杭の水平載 荷試験およびシミュレーション解析, 構造工学論文集, 土 木学会, Vol.39A, pp.1371-1384, 1993.

14）木村亮, 幸左賢二, 伊藤恭平, 坂本眞徳 : 場所打ち杭の大 変形水平挙動に関する研究, 構造工学論文集, 土木学会, Vol.39A, pp. 1385-1394, 1993.

15）斎藤亮, 飯古道則, 五瀬伸吾, 易鋒 : 杭基礎の水平方向大 変形の挙動に関する研究, 構造工学論文集, 土木学会, Vol.39A, pp.1395-1408, 1993.

16）富永晃司, 山肩邦男 : 地盤の塑性状態を考慮した群ぐいの 水平抵抗理論一その 1 塑性地盤反力について一, 日本建
築学会論文報告集, 第317号, pp.32-39, 1982.

17) Schnabel, P.B., Lysmer, J. and Seed, H.B. : SHAKE-A Computer Program for Earthquake Response Analysis of Horizontally Layered Sites, Report No. EERC 72-12, University of California at Berkeley, 1972.

18）たとえば, 風間基樹, 柳沢栄司, 稲富隆昌, 管野高弘, 稲 垣紘史 : アレー観測記録から推定した神戸ポートアイラ ンドの地盤の応力ーひずみ関係，土木学会論文集，№.547， pp.171-182, 1996.

19）宮本裕司, 酒向裕司, 喜多村英司, 三浦賢治 : 非線形, 液 状化地盤における杭基礎の地震応答性状に関する研究, 日本建築学会構造系論文集, 第471号, pp.41-50, 1995.

20）（財）日本気象協会 : 平成 7 年兵庫県南部地震の気象庁 87 型電磁式強震計の記録, 1995.

21) Yutaka, N.: Waveform and its Analysis of the 1995 Hyogo-KenNanbu Earthquake, JR Earthquake Information, No.23c, Railway Technical Research Institute, 1995.

22) CSMIP: Processed CSMIP Strong motion records from the Northridge, California Earthquake of January 17 1994, Release No.1, Report No.OSMS94-06B, 1994.

23）（財）日本気象協会 : 平成 5 年釧路沖地震の気象庁 87 型電 磁式強震計の記録, 1993.

24）矢部正明, 川島一彦 : 地震時保有水平耐力法による杭基礎 の耐震設計法に関する研究（その1），Report No.TIT/EERG98- 1, 1998.

(1998. 2.6 受付)

\title{
NONLINEAR SEISMIC RESPONSE OF A PILE FOUNDATION AND ITS PUSH-OVER ANALYSIS
}

\section{Masaaki YABE and Kazuhiko KAWASHIMA}

\begin{abstract}
When a large earthquake occurs, plastic deformation is developed not only in the reinforced concrete piers but the pile foundation of a bridge. Since the nonlinear behavior of the pier and that of the pile foundation is interacted, it is required to evaluate the lateral load which should be applied to the pile foundation in the push over-analysis, considering the flexural strength of the pier. This paper describes a series of nonlinear analysis and the push-over analysis for a bridge. It is found from the analysis that the push-over analysis provides sufficient accuracy for evaluating the deformation of the piles if the contribution of damping force, in addition to the flexural strength of pier, is considered to evaluate the lateral load, and if the deformation of the surrounding soils is considered.
\end{abstract}

